\title{
Zic4-Lineage Cells Increase Their Contribution to Visual Thalamic Nuclei during Murine Embryogenesis If They Are Homozygous or Heterozygous for Loss of Pax6 Function
}

\author{
(1)Ziwen Li, ${ }^{1}$ (1)Thomas Pratt, ${ }^{1}$ and David J. Price ${ }^{1}$
}

https://doi.org/10.1523/ENEURO.0367-18.2018

${ }^{1}$ Simons Initiative for the Developing Brain, Biomedical Sciences, The University of Edinburgh, Edinburgh EH8 9XD, United Kingdom

\begin{abstract}
Our aim was to study the mechanisms that contribute to the development of discrete thalamic nuclei during mouse embryogenesis (both sexes included). We characterized the expression of the transcription factor coding gene Zic4 and the distribution of cells that expressed Zic4 in their lineage. We used genetic fate mapping to show that Zic4-lineage cells mainly contribute to a subset of thalamic nuclei, in particular the lateral geniculate nuclei (LGNs), which are crucial components of the visual pathway. We observed that almost all Zic4-lineage diencephalic progenitors express the transcription factor Pax6 at variable location-dependent levels. We used conditional mutagenesis to delete either one or both copies of Pax6 from Zic4-lineage cells. We found that Zic4-lineage cells carrying either homozygous or heterozygous loss of Pax6 contributed in abnormally high numbers to one or both of the main lateral geniculate nuclei (LGNs). This could not be attributed to a change in cell production and was likely due to altered sorting of thalamic cells. Our results indicate that positional information encoded by the levels of Pax6 in diencephalic progenitors is an important determinant of the eventual locations of their daughter cells.
\end{abstract}

Key words: lateral geniculate nucleus; Pax6; prethalamus; thalamus; Zic4

\section{Significance Statement}

The development of the thalamus is a process in which cells that initially appear similar give rise to distinct cell groups called nuclei. How these nuclei form is poorly understood. We utilized a mouse model in which cells that express the gene Zic4 can be followed. We studied the consequences of knocking out either one or both copies of the gene encoding the Pax6 transcription factor in these Zic4-lineage cells. We found that these mutations had significant effects on the contribution of Zic4-lineage cells to specifically visual thalamic nuclei. This was not attributable to a change in Zic4-lineage cell production in mutants. Rather, we suggest that mutation of Pax6 affects the distribution of Zic4-lineage neurons to specific thalamic nuclei.

\section{Introduction}

The diencephalon is one of the two major components of the vertebrate forebrain. It contains several structures

Received September 20, 2018; accepted September 22, 2018; First published October 9, 2018.

The authors declare no competing financial interests.

Author contributions: Z.L., T.P., and D.J.P. designed research; Z.L. performed research; Z.L. analyzed data; Z.L. and D.J.P. wrote the paper. essential for brain function, including the thalamus and prethalamus. The thalamus is an important regulator of fundamental processes including sleep, alertness, con-

This work was supported by the Medical Research Council Grant MR/ N012291/1 (to D.J.P.) and by an Edinburgh University Global Research Scholarship and Principal's Career Development Scholarship (Z.L.).

Acknowledgements: We thank the staff at the University of Edinburgh for invaluable help with mouse maintenance; Thomas Theil and Nicoletta Kessaris 
sciousness and cognition, and is involved in the regulation of corticocortical communication and the relaying of sensory information to the cerebral cortex (Sherman and Guillery, 2002, 2006, 2011; Jones 2007). The thalamus is commonly subdivided into $>40$ distinct nuclei, distinguished according to their function, cytoarchitecture, anatomic connectivity and gene expression patterns (Jones, 2007; Lim and Golden, 2007; Martinez-Ferre and Martinez, 2012). For example, the lateral geniculate nucleus (LGN) is essential for the processing of visual information. The LGN is divided into two major components: the dorsal LGN (dLGN) relays visual signals from the retina to the visual cortex; the ventral LGN (vLGN) is involved in processing and integration, having inputs from retina, cortex, and superior colliculus and connections to other thalamic nuclei.

Thalamic nuclei develop in the mouse embryo during the final third of gestation as neurons generated from progenitors lining the third ventricle migrate radially into the thalamic mantle zone (Nakagawa and Shimogori, 2012). This process is likely to be regulated by the transcription factor Pax6, which is expressed by most diencephalic progenitors. The relatively few exceptions are located at the zona limitans intrathalamica (ZLI) between the thalamus and prethalamus (Macdonald et al., 1995; Ericson et al., 1997; Robertshaw et al., 2013; Caballero et al., 2014). The expression level of Pax6 varies systematically across the thalamus from high (caudally) to low (rostrally) and is high in the prethalamus. It can, therefore, confer positional identity on diencephalic progenitors, which might contribute to the ability of their daughter neurons to coalesce into discrete nuclei later in development.

Zic4 is a zinc finger transcription factor expressed in embryonic mouse nervous system, including the diencephalon, from embryonic day (E)9.5 on (Aruga et al., 1996a,b; Gaston-Massuet et al., 2005). A previous study reported that it is highly expressed in the postnatal LGN (Horng et al., 2009). We began our study by testing whether cells related by the expression of Zic4 at some time in their lineage (referred to as Zic4-lineage cells) contribute selectively to specific thalamic nuclei. We conducted a detailed analysis of the development of both Zic4 expression and the distributions of Zic4-lineage cells in the embryonic diencephalon and found that Zic4lineage cells are distributed preferentially to a select subset of thalamic nuclei, in particular the vLGN, by the time

\footnotetext{
for the Zic4 ${ }^{\text {Cre }}$ mice; Nicoletta Kessaris for the Zic4 plasmids; Dr. Martine Manuel for advising and colony managing; Anisha Kubasik-Thayil for helping with confocal microscopy; Vivian Alison and Louis Dunn for helping with histology; and Mike Molinek for supervising the laboratory work.

Correspondence should be addressed to David J. Price, University of Edinburgh, Hugh Robson Building, George Square, Edinburgh EH8 9XD, United Kingdom, E-mail: david.price@ed.ac.uk.

https://doi.org/10.1523/ENEURO.0367-18.2018

Copyright (C) 2018 Li et al.

This is an open-access article distributed under the terms of the Creative Commons Attribution 4.0 International license, which permits unrestricted use, distribution and reproduction in any medium provided that the original work is properly attributed.
}

of birth. We then studied the consequences of Zic4 $4^{\text {Cre }}$ induced deletions of either one or both copies of Pax6.

\section{Materials and Methods}

\section{Mice}

All experiments were conducted in accordance with Home Office United Kingdom regulations and University of Edinburgh animal welfare guidelines.

Conditional Pax6 knock-out mice were generated by crossing floxed Pax6 mutant mice Pax $6^{f l / f l}$ (Simpson et al., 2009) with Zic4 ${ }^{\text {Cre }}$ mice (Rubin et al., 2010), a kind gift from Dr. Thomas Theil at Center for Discovery Brain Sciences at the University of Edinburgh. These mice were crossed with RCE:loxP mice (Miyoshi et al., 2010) to report the Cre activity with the expression of an enhanced green fluorescent protein (EGFP; subsequently referred to as GFP). The triple transgenic mice were maintained on a C57BL/6 background. To obtain Zic4 ${ }^{\mathrm{Cre}+/-}$;Pax6 $6^{\mathrm{fl} / \mathrm{fl} \text {; }}$ $\mathrm{RCE}^{+/-}, \mathrm{Zic}^{\mathrm{Cre}+/-}$;Pax6 $6^{\mathrm{fl} /+} ; \mathrm{RCE}^{+/-}$, and $\mathrm{Zic} 4^{\mathrm{Cre}+/-}, \mathrm{Pax}^{+/+}$; $R C E^{+/-}$embryos (subsequently referred to as $P a x 6^{f / / f l}$, $P a x 6^{f l /+}$, and $P_{a x 6^{+/+}}$), Pax6 $6^{f / /+} ; R C E^{+/-}$females were crossed with Pax6 $6^{f / /+} ; Z_{i c} 4^{\mathrm{Cre}+/-}$ males. To obtain Zic4 ${ }^{\mathrm{Cre}+/-} ; \mathrm{RCE}^{+/-}$embryos, $R C E^{+/-}$females were crossed with Zic4 ${ }^{\mathrm{Cre}+/-}$ males.

\section{Genotyping}

Zic4 ${ }^{\text {Cre }+/-}$ mice were genotyped using primers (forward: GAGGGACTACCTCCTGTACC, reverse: TGCCCAGAGTCATCCTTGGC) to the iCre cassette (Rubin et al., $2010)$, resulting in a 630-bp PCR product in the mutant. $R C E^{+/-}$mice were genotyped using three primers (Rosa1: CCCAAAGTCGCTCTGAGTTGTTATC; Rosa2: GAAGGA GCGGGAGAAATGGATATG; and Cag3: CCAGGCGG GCCATTTACCGTAAG) to the EGFP reporter (Miyoshi et al., 2010), resulting in a 550-bp PCR product in the wild type and a 350-bp PCR product in the mutant. Mice

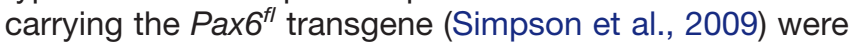
genotyped using two primers (FP6GtF: AAATGGGGGTGA AGTGTGAG; FP6GtR: TGCATGTTGCCTGAAAGAAG), resulting a 156-bp PCR product in the wild type and a 195-bp PCR product in the mutant.

All Zic4 $4^{\mathrm{Cre}+/-} ; \mathrm{RCE}^{+/-}$embryos and pups were distinguished from wild-type mice based on the detection of the GFP reporter using a GFP stereoscope and genotyped for the $P a x 6^{f l}$ transgene using the primers described above.

\section{Tissue preparation and histology}

The day that the vaginal plug was found was considered as E0.5. For postnatal studies, the birth date was considered as postnatal day $(P) 0$. Embryos were extracted from pregnant females by caesarean section following an overdose of isoflurane and were harvested into ice-cold PBS. For embryos aged from E11.5 to E14.5, whole heads were removed and fixed in $4 \%(\mathrm{w} / \mathrm{v})$ paraformaldehyde (PFA) in PBS overnight at $4^{\circ} \mathrm{C}$. For embryos aged from E15.5 to E18.5, brains were dissected from skulls before proceeding to fixation. P0 pups were anaesthetized by an overdose of sodium pentobarbitone and perfused with 4\% PFA through the left ventricle of the 
heart. The brains were extracted and immersed in $4 \%$ PFA for $48 \mathrm{~h}$ at $4^{\circ} \mathrm{C}$.

Fixed samples were either dehydrated in $70 \% \mathrm{EtOH}$ and embedded in paraffin for microtome sectioning or cryo-protected in $30 \%$ sucrose (w/v) in PBS, embedded in a 1:1 mixture of $30 \%$ sucrose $(\mathrm{w} / \mathrm{v})$ in PBS and optimal cutting temperature (OCT) compound (Tissue-Tek, Sakura Finetek Europe), and frozen on dry ice for cryostat sectioning. All samples were sectioned coronally at $10 \mu \mathrm{m}$.

\section{Fluorescent in situ hybridization}

The digoxigenin (DIG)-labeled Zic4 antisense RNA probe was used at a concentration of 1:2000. Fluorescent in situ hybridizations were performed according to a published protocol (Rubin et al., 2010). The plasmid used to generate the Zic4 probe was the IMAGE clone 6400880 (linearised with EcoRI and transcribed with T3 RNA polymerase), a kind gift from Professor Nicoletta Kessaris, Wolfson Institute for Biomedical Research, University College London, United Kingdom.

\section{Immunohistochemistry}

Fluorescent immunohistochemistry was performed on paraffin embedded sections according to previously published protocols (Martynoga et al., 2005). Diaminobenzidine (DAB) immunohistochemistry for Pax6 was performed using the Vectastain ABC kit (Vector Laboratories) following an incubation of slides in biotinylated secondary antibodies and slides were incubated in 3\% hydrogen peroxide $/ 90 \%$ methanol for 30 min to inactivate endogenous peroxidase activities during the rehydration process.

Primary antibodies used were as follow: mouse antiBrdU IgG1 (1:150, BD Biosciences, RRID:AB_10015219), rabbit anti-Ki67 IgG (1:500, Abcam, RRID:AB_2049848), rabbit anti-pHH3 (Ser10; 1:100, Millipore), mouse antiTuj1 IgG (1:400, Abcam), goat anti-GFP IgG (1:150, Abcam), mouse anti-COUP-TFI lgG $\lg _{2 A}(1: 500, R \& D$ Systems, RRID:AB_1964211), mouse anti-COUP-TFII IgG $\lg _{2 A}(1: 1000$, R\&D Systems, RRID:AB_1964214), mouse anti-LIM1/2 [1: 50, Developmental Studies Hybridoma Bank (DSHB), University of lowa], mouse anti-Nkx2.2 (1:200, DSHB), and mouse anti-Pax6 (AD2.38; a kind gift from Professor Veronica Van Heyningen at Institute of Genetics and Molecular Medicine, University of Edinburgh).

Secondary antibodies used were donkey anti-goat Alexa Fluor 488 (1:200, Invitrogen), rabbit anti-mouse biotin (1:200, Vector Laboratories), goat anti-rabbit biotin (1:200, Vector Laboratories), streptavidin Alexa Fluor 594 (1:200, Invitrogen), donkey anti-mouse Alexa Fluor 568 (1:200, Invitrogen), donkey anti-mouse Alexa Fluor 647 (1:200, Invitrogen), and donkey anti-rabbit Alexa Fluor 647 (1:200, Invitrogen).

\section{Bromodeoxyuridine (BrdU) labeling}

A single dose of $\mathrm{BrdU}(70 \mu \mathrm{g} / \mathrm{g}$ mouse weight, diluted in saline $10 \mu \mathrm{g} / \mu \mathrm{l}$ ) was administrated via intraperitoneal injection to pregnant dams carrying E10.5, E11.5, E12.5, and E13.5 embryos. For birthdate studies, brain tissue was collected from four PO Zic4Cre ${ }^{+/-} ; \mathrm{RCE}^{+/-} ; \mathrm{Pax}^{+/+}$ pups for each injection age (E10.5-E13.5). For cell proliferation studies, four embryos were collected for brain tissue $1.5 \mathrm{~h}$ after injection for each injection age (E11.5E12.5).

\section{Imaging, image processing, and cell counting}

DAB images were taken with a Leica DFC480 camera connected to a Leica DMNB epifluorescence microscope. Fluorescence images were taken with a Leica DM5500B automated upright microscope connected to a DFC360FX camera and a Nikon A1R confocal microscope.

For birthdating studies, vLGN, dLGN, and ventral posterior (VP) nuclei were outlined and processed in CellProfiler (Lamprecht et al., 2007) using a custom pipeline. RGB images were split into three single-channel gray scale images and a global thresholding was performed to reduce background noises. Cell nuclei were identified using DAPI staining and a cutoff intensity value of 5 was used to distinguish nuclei with positive or negative staining for both BrdU and GFP. All cell nuclei were classified and automatically counted into four categories: GFP-BrdU-, GFP-BrdU+, GFP+BrdU+, and GFP+BrdU-, and proportions of each category were calculated and exported into spreadsheets.

For cell proliferation studies, a box with a fixed width was positioned and stretched to include the whole diencephalic wall for three structures of interest: the prethalamus and the pTH-R and pTH-C in the thalamus. Cropped images were processed in CellProfiler. Cell nuclei segmentation and fluorescence intensity measurements for BrdU, pHH3, Ki67, Tuj1, and GFP were performed as described above, with the same intensity cutoff applied ahead of cell counting.

For cell contribution studies, volumes of vLGN, dLGN, and VP were estimated using the ImageJ Volumest plugin (Merzin, 2008) using a series of 10 coronal sections with a regular interval of $60 \mu \mathrm{m}$. Within each section, nuclei were outlined and overlaid with a counting grid. $30 \%$ of counting tiles $(30 \times 30 \mu \mathrm{m})$ were randomly sampled using a custom ImageJ plugin (inspired by Wayne Rasband's ImageJ plugin Grid) and manually counted to calculate densities of all cells and GFP + cells. The number of all cells in each nucleus was calculated by multiplying its volume and cell density.

\section{Code accessibility}

Custom CellProfiler pipeline and ImageJ sampling tile generator plugin will be provided on request.

\section{Statistical analyses}

Statistical analyses were conducted using the Prism 7 statistical software (version 7.01, GraphPad Software Inc.). Univariate statistics (mean \pm SEM) were performed for all studied variables. One-way ANOVA was performed to study the effect of genotype, and two-way ANOVA was performed to examine the effects of genotype and anterior-posterior position. The Tukey's post hoc test was performed for all pair-wise comparisons subsequent to the ANOVAs. 


\section{Results}

\section{Zic4 and Zic4 ${ }^{\text {Cre }}$ expression in the embryonic diencephalon}

We began by thoroughly analyzing and comparing the expression of Zic4 transcripts and GFP reporter in the $\mathrm{Zic}_{4} \mathrm{Cre}^{+/-} ; \mathrm{RCE}^{+/-}$diencephalon at embryonic stages from E11.5 to birth (Figs. 1-3). Whereas in situ hybridizations for Zic4 mRNA revealed the expression patterns of the gene at the time of analysis, GFP revealed cells that were either expressing or at some time in their past expressed Zic4 (Zic4-lineage cells).

In the E11.5 diencephalon (Fig. 1A-F), Zic4 transcripts were detected at highest levels in cells of the prethalamus (Fig. 1C1,D1) and the eminentia thalami (Fig. 1B1). In the prethalamus, the Zic4 transcripts were concentrated in cells on the outer, pial side of the neuroepithelium (Fig. 1E). GFP expression overlapped that of Zic4 transcripts, with GFP+ cells most frequent in the prethalamus and the eminentia thalami (Fig. 1B2,C2,D2). GFP reporter activity did not correspond perfectly to the expression of Zic4 transcripts, with many Zic4+ cells being GFP negative (Fig. $1 E, F)$. The most likely explanation for this was that insufficient time had elapsed following the onset of Zic4 expression for the production of detectable levels of GFP. This delay would have been for the production of Cre recombinase from the Zic4Cre transgene, the consequent activation of the reporter gene and the production of sufficient GFP.

At E12.5, Zic4 transcripts were present more widely, from epithalamus through thalamus and prethalamus to eminentia thalami (Fig. 1H1-J1). Expression levels were still highest in the prethalamus, as at E11.5, but were also strong in the epithalamus. In the thalamus, expression levels were highest in more anterior sections. GFP expression showed very similar patterns (Fig. 1H2-J2).

These E12.5 patterns of Zic4 and GFP expression were largely maintained as the tissues grew in size over subsequent days up to birth (Figs. 2, 3). As thalamic nuclei formed during this period, Zic4/GFP+ cells became concentrated in the vLGN, around the border between the thalamus and prethalamus, in anterior thalamic regions and in the epithalamus. By birth, the densest concentration of GFP+ Zic4-lineage cells was in vLGN and the medial habenula of the epithalamus (Fig. $3 H, I)$. Their densities were intermediate in other lateral thalamic nuclei such as the dLGN and in the zona incerta (ZI) of the prethalamus. They were low in midline thalamic nuclei such as nucleus reuniens and the rhomboid nucleus, and almost absent from VP thalamic nuclei such as the ventral posterolateral nucleus (VPL) and ventral posteromedial nucleus (VPM; Fig. $3 H, I)$.

These findings indicate that Zic4-lineage diencephalic progenitors contribute their daughter cells mainly to the thalamic nuclei that are close to the boundary between thalamus and prethalamus, particularly to the vLGN but also to others such as the dLGN.

\section{Overlap between Zic4-lineage and Pax6-expressing cells}

The normal expression pattern of Pax6 is shown at E12.5, E13.5, E14.5, and E16.5 in Figures 4A1-F1, 5A1-G1,
6A1-G1,7A1-F1. Pax6 is expressed at some level in almost all progenitors throughout the epithalamus, thalamus, prethalamus, and eminentia thalami, the exceptions being located in the ZLI, a small strip of tissue between the thalamus and prethalamus (Fig. 4E1). In thalamus, it is distributed in a gradient with the lowest levels close to the border with the prethalamus (Figs. 4A1-E1, 5A1-E1). Since it is not expressed by postmitotic thalamic neurons, it almost completely disappears once the progenitor population is exhausted by E16.5 (Fig. 7A1-F1).

In the prethalamus, Pax6 is strongly expressed by progenitors and is retained by many postmitotic cells as they migrate radially into the diencephalic mantle zone (Figs. $4 A 1-E 1,5 A 1-E 1,6 A 1-G 1)$. These cells form a Pax6positive strip running across the prethalamus. At early stages, some of them migrate as far as the outer edge of the neuroepithelium to a region where the VLGN will form (Fig. 5B1-E1,G1). By E14.5, when the development of discrete diencephalic nuclei is underway, most Pax6expressing cells are located in the $\mathrm{Zl}$ of the prethalamus (Fig. 6A1-G1). At E14.5 and E16.5, we observed small numbers of Pax6-expressing cells in the vicinity of the vLGN, mostly around rather than within it (Figs. 6E1-G1, 7D1-F1).

As expected, given that Pax6 is expressed by almost all thalamic and prethalamic progenitors, double-label experiments showed that Zic4-lineage thalamic and prethalamic progenitor cells express Pax6 as early as E11.5 (Fig. 8). Many Zic4-lineage postmitotic cells in the prethalamus retained Pax6 (e.g., yellow asterisks in Fig. $8 C$ ); others did not (e.g., green asterisks in Fig. $8 C$ ). We went on to use the Zic $4^{\text {Cre }}$ allele to test the effects of mutating one or both copies of the Pax6 gene in Zic4lineage cells.

\section{Zic4 ${ }^{\text {Cre }}$-induced deletion of Pax6}

We studied Pax6 expression in Zic4 ${ }^{\mathrm{Cre}} ; \mathrm{Pax} 6^{\mathrm{fl}++}$ and $\mathrm{Zic4}^{\mathrm{Cre}} ; \mathrm{Pax}^{\mathrm{fl} / \mathrm{fl}}$ embryos at E12.5, E13.5, E14.5, and E16.5. For each genotype at each age, we examined three non-littermate embryos and the results were indistinguishable. In Zic4 ${ }^{\mathrm{Cre}} ; \mathrm{Pax}^{\mathrm{fl} / \mathrm{fl}}$ homozygous mutant embryos (Figs. 4A3-F3, 5A3-G3, 6A3-G3, 7A3-F3), the numbers of cells immunostained for Pax 6 declined rapidly in the thalamus from E12.5 onwards, particularly in its anterior parts where many cells are Zic4-lineage. By E14.5, there were almost no Pax6-expressing progenitors in the thalamus in Zic4 ${ }^{\mathrm{Cre}} ; \mathrm{Pax} 6^{\text {fl/fl }}$ embryos whereas normally a small population remained. The numbers of Pax6expressing cells in the prethalamus of $\mathrm{Zic}^{\mathrm{Cre}}{ } \mathrm{Pax}^{\mathrm{ff} / \mathrm{fl}}$ embryos were greatly reduced at all ages. There were no consistent defects in the overall shapes and sizes of diencephalic structures.

In Zic4 ${ }^{\mathrm{Cre}} ; \mathrm{Pax}^{\mathrm{fl} /+}$ heterozygotes, we detected no defects of Pax6 expression at E12.5-E14.5 (Figs. 4A2-F2, $5 A 2-G 2,6 A 2-G 2)$. By E16.5, however, the numbers of Pax6-expressing cells had declined throughout the prethalamus and the intensity of the immunostaining of many Pax6-expressing cells was lower than normal (Fig. 7A2-F2). The pattern of Pax6 expression in Zic4 ${ }^{\text {Cre }}$; 
A

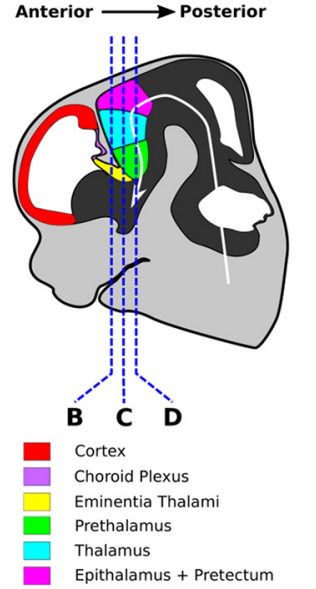

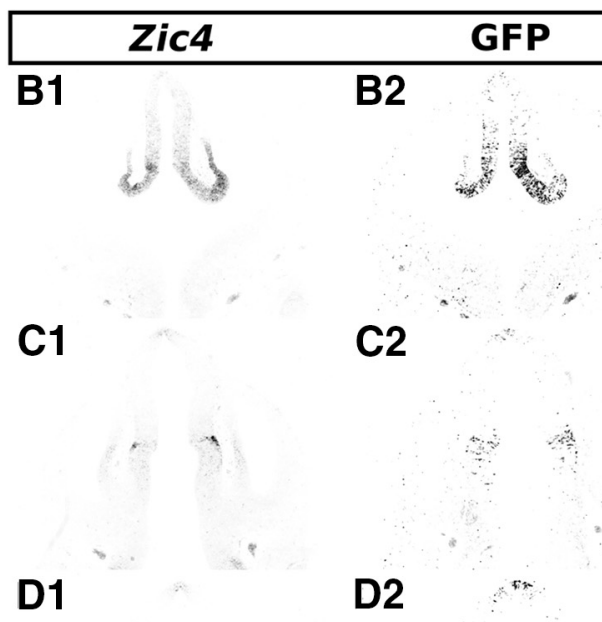

D1
G

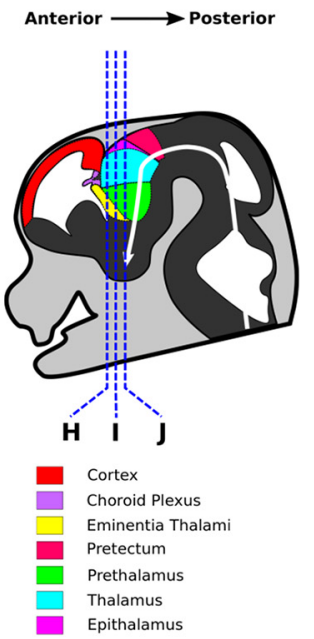

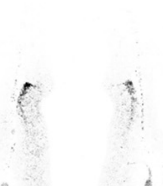

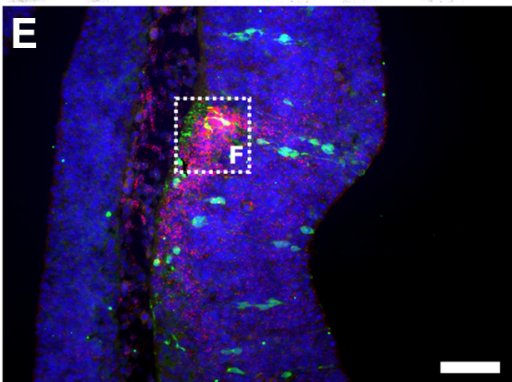

H1

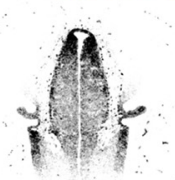

H2

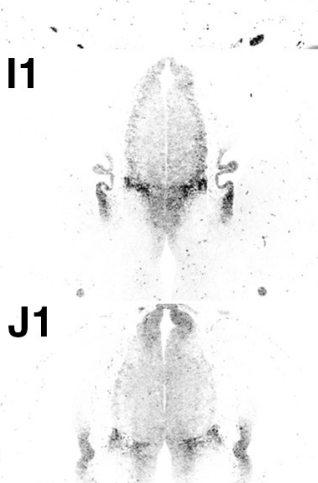

12

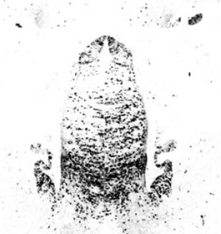

$\mathrm{J} 2$

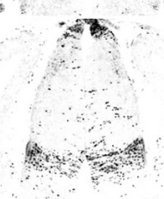

Zic4GFPDAPI

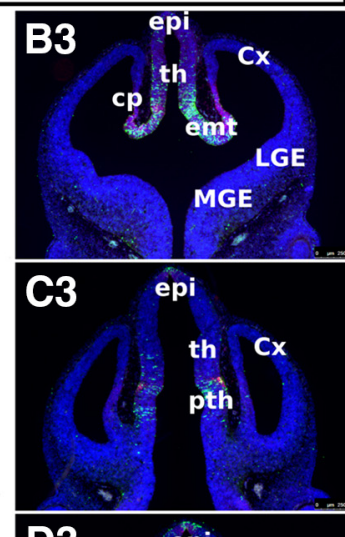

th
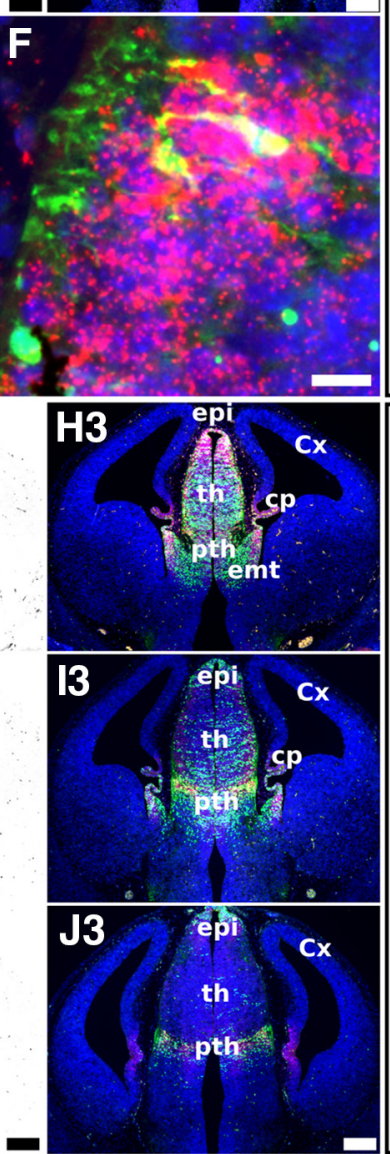

䍐

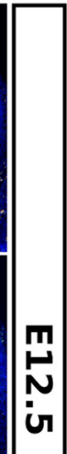

Figure 1. Expression of Zic4 and activity of Zic4 ${ }^{\mathrm{Cre}}$ in Zic4 ${ }^{\mathrm{Cre}+/-} ; R C E^{+/-}$mouse brain coronal sections at E11.5 and E12.5. A, G, Schematics of E11.5 and E12.5 mouse brain demarcating major subdivisions and sectioning planes. B1-F, H1-J3, Zic4 fluorescent in situ hybridization (monochrome in $\mathbf{B 1}, \mathbf{C 1}, \mathbf{D 1}, \boldsymbol{H 1}, \boldsymbol{I 1}, \mathbf{J 1}$ or red in $\mathbf{B 3}, \mathbf{C} \mathbf{3}, \mathbf{D} \mathbf{3}, \boldsymbol{E}, \boldsymbol{F}, \boldsymbol{H} \mathbf{3}, \mathbf{I 3}, \mathbf{J} \mathbf{3}$ ) and immunohistochemistry for GFP reporter of Zic4 ${ }^{\text {Cre }}$ activity (monochrome in $\mathbf{B 2}, \mathbf{C 2}, \mathbf{D 2}, \mathbf{H 2}, \mathbf{I 2}, \mathbf{J} \mathbf{2}$ or green in $\left.\mathbf{B 3}, \mathbf{C} \mathbf{3}, \mathbf{D} \mathbf{3}, \boldsymbol{E}, \boldsymbol{F}, \boldsymbol{H} \mathbf{3}, \mathbf{I 3}, \mathbf{J} \mathbf{3}\right)$ with DAPI counterstaining (blue). Box in $\boldsymbol{D} 3$ is shown in $\boldsymbol{E}$; box in $\boldsymbol{E}$ is shown in $\boldsymbol{F}$. Scale bars: $250 \mu \mathrm{m}$ (B1-D3, $\boldsymbol{H 1}-\boldsymbol{J} \mathbf{3}), 125 \mu \mathrm{m}(\boldsymbol{E}), 25 \mu \mathrm{m}(\boldsymbol{F})$. Cx, cortex; cp, choroid plexus; MGE, medial ganglionic eminence; LGE, lateral ganglionic eminence; th, thalamus; pth, prethalamus; emt, eminentia thalami; epi, epithalamus. 
A

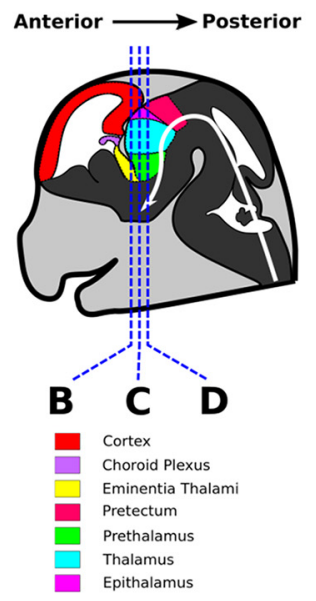

E

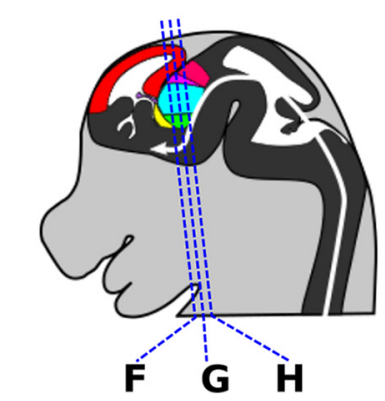

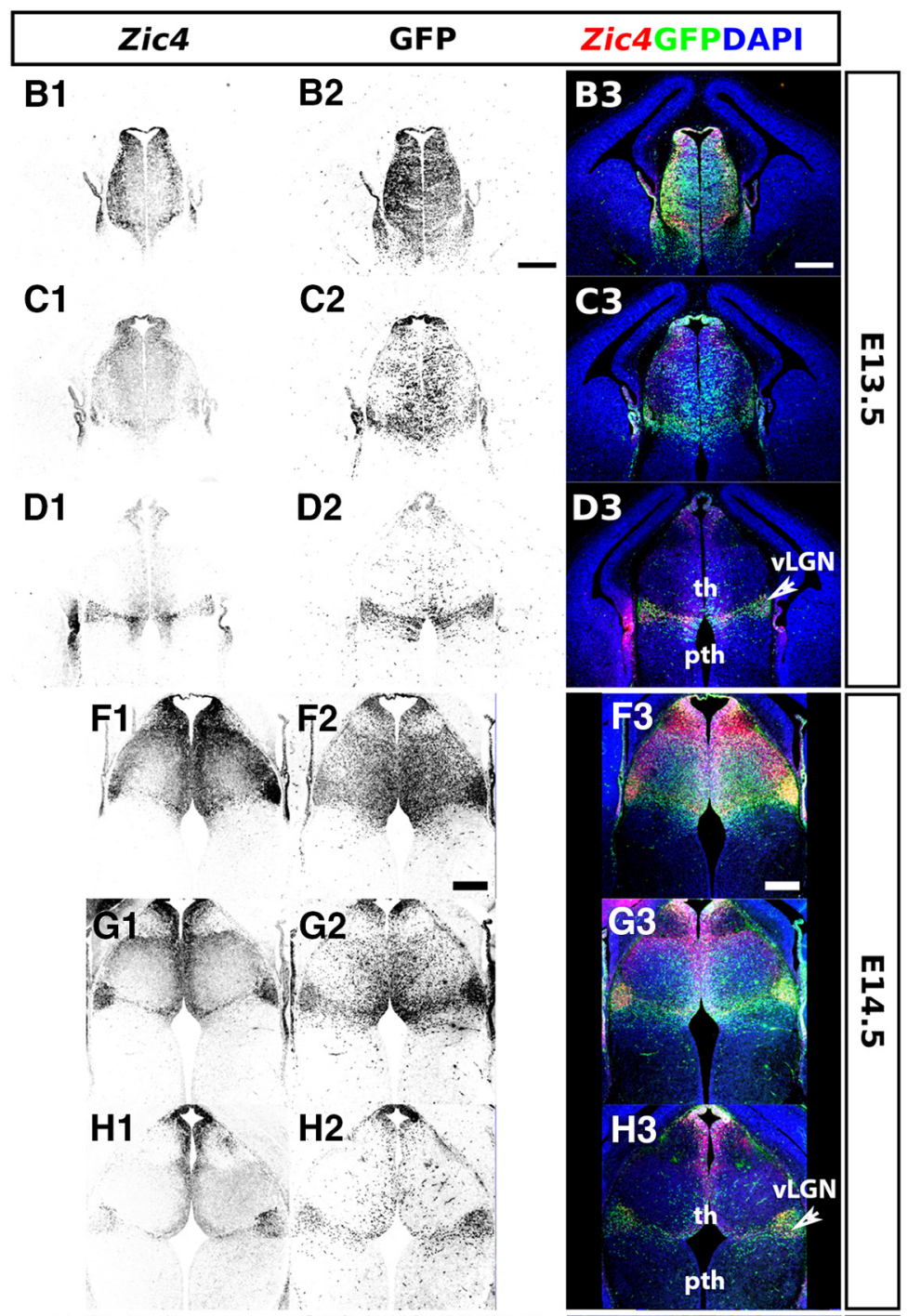
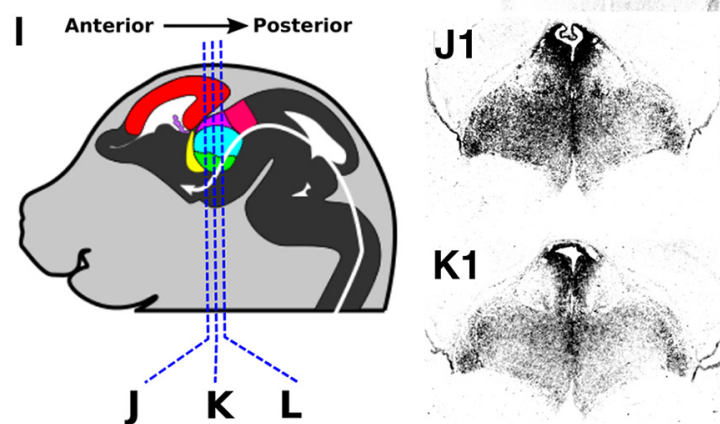

$\mathrm{J} 2$
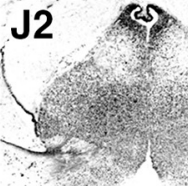

K2

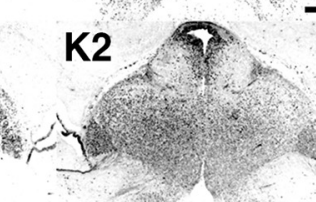

J3
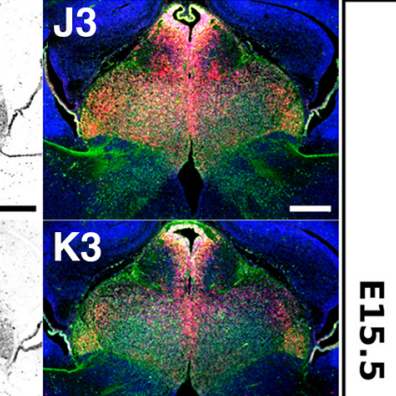
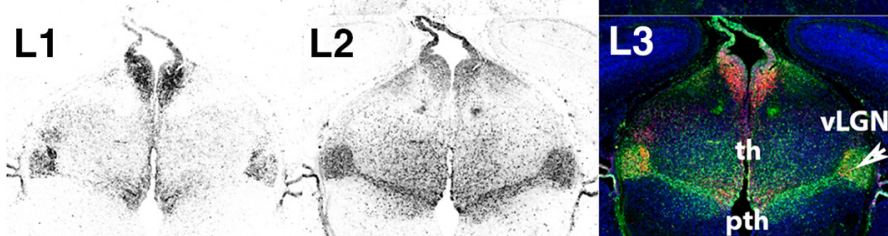

Figure 2. Expression of Zic4 and activity of Zic4 ${ }^{\mathrm{Cre}}$ in Zic4 ${ }^{\mathrm{Cre}+/-} ; \mathrm{RCE}^{+/-}$mouse brain coronal sections at E13.5, E14.5, and E15.5. $\boldsymbol{A}, \boldsymbol{E}, \boldsymbol{I}$, Schematics of E13.5, E14.5, and E15.5 mouse brain demarcating major subdivisions and sectioning planes. B1-D3, $\boldsymbol{F 1 - H 3 ,}$ $\boldsymbol{J 1 - L 3 , ~ Z i c 4 ~ f l u o r e s c e n t ~ i n ~ s i t u ~ h y b r i d i z a t i o n ~ ( m o n o c h r o m e ~ i n ~ B 1 , ~ C 1 , ~ D 1 , ~ F 1 , ~ G 1 , ~ H 1 , ~ J 1 , ~ K 1 , ~ L 1 ~ o r ~ r e d ~ i n ~ B 3 , ~ C 3 , ~ D 3 , ~ F 3 , ~ G 3 , ~ H 3 , ~}$ J3, K3, L3) and immunohistochemistry for GFP reporter of Zic4 ${ }^{C r e}$ activity (monochrome in B2, C2, D2, F2, G2, H2, J2, K2, L2 or green in B3, C3, D3, F3, G3, H3, J3, K3, L3) with DAPI counterstaining (blue). Scale bars: $250 \mu \mathrm{m}$. vLGN, ventral lateral geniculate nucleus; th, thalamus; pth, prethalamus. 
A

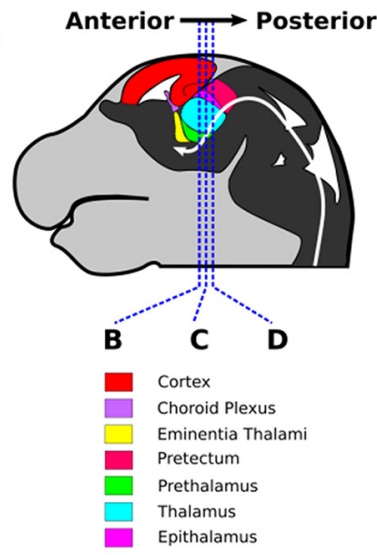

E

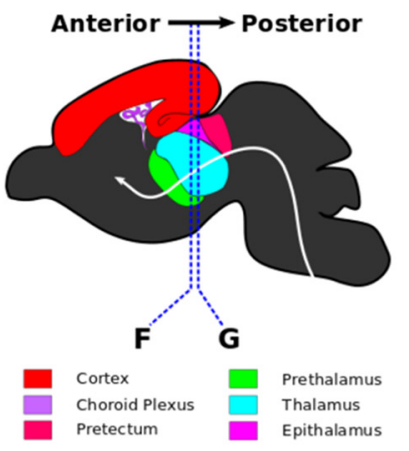

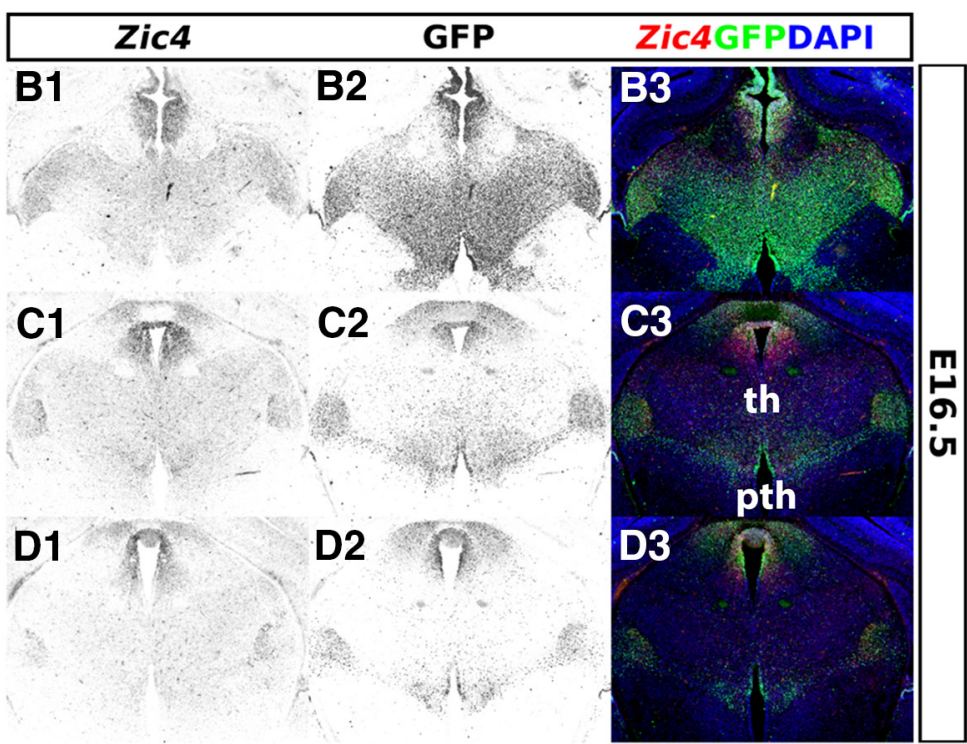

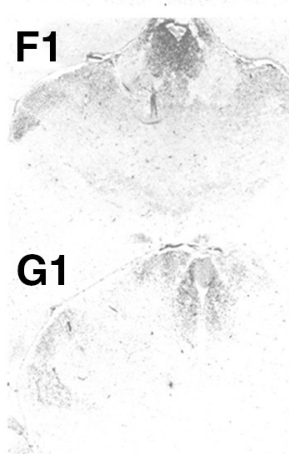

F2

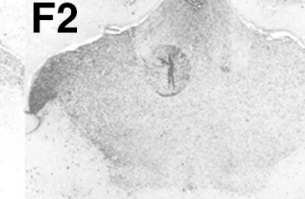

G2

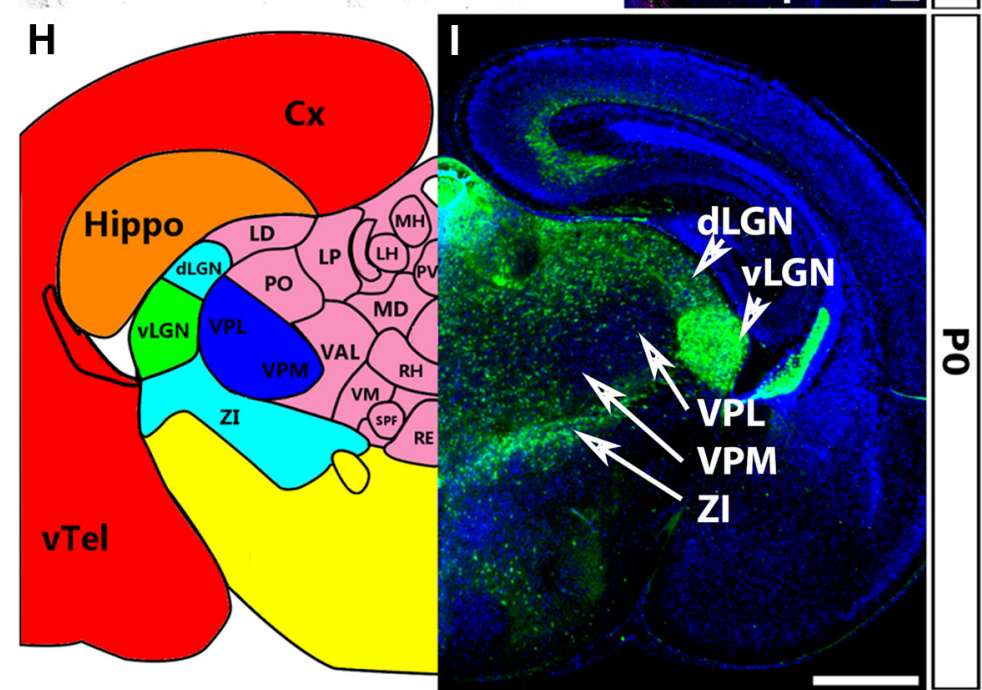

Figure 3. Expression of Zic4 and activity of Zic4 ${ }^{\mathrm{Cre}}$ in $\mathrm{Zic} 4^{\mathrm{Cre}+/-} ; R C E^{+/-}$mouse brain coronal sections at E16.5, E18.5, and P0. A, $\boldsymbol{E}, \boldsymbol{H}$, Schematics of E16.5, E18.5, and P0 mouse brain demarcating major subdivisions and nuclei and sectioning planes. B1-D3, F1-G3, Zic4 fluorescent in situ hybridization (monochrome in B1, C1, D1, F1, G1 or red in B3, C3, D3, F3, G3) and immunohistochemistry for GFP reporter of Zic4 ${ }^{\text {Cre }}$ activity (monochrome in B2, C2, D2, F2, G2 or green in B3, C3, D3, F3, G3, I) with DAPI counterstaining (blue). Scale bars: $250 \mu \mathrm{m}$ (B1-G3), $500 \mu \mathrm{m}(\boldsymbol{I})$. Cx, cortex; dLGN, dorsal lateral geniculate nucleus; Hippo, hippocampus; LD, lateral dorsal nucleus; LH, lateral habenula; LP, lateral posterior nucleus; MD, medial dorsal nucleus; MH, medial habenula; PO, posterior nucleus; pth, prethalamus; PV, paraventricular nucleus; RE, nucleus reunions; RH, rhomboid nucleus; SPF, subparafascicular thalamic nucleus; th, thalamus; VAL, ventral anterolateral nucleus; vLGN, ventral lateral geniculate nucleus; VM, ventromedial nucleus; VPL, ventral posterolateral nucleus; VPM = ventral posteromedial nucleus; vTel, ventral telencephalon; ZI, zona incerta. $\boldsymbol{H}$, Adapted from Allen Brain Atlas (http://developingmouse.brain-map.org/). 

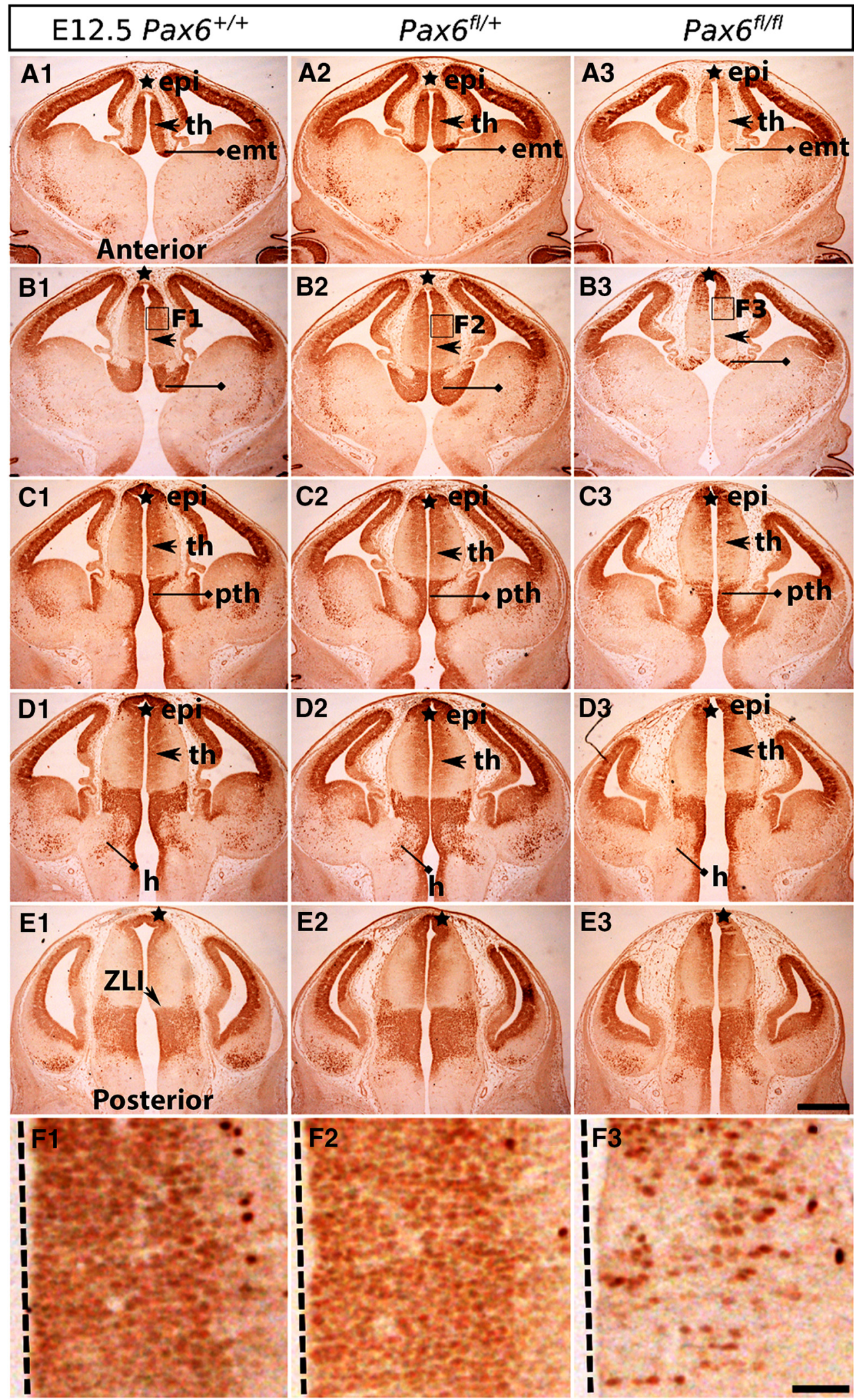

Figure 4. Pax6 expression in control and Pax6 mutant embryos at E12.5. Immunohistochemistry for Pax6 on a set of sections cut through the diencephalon in similar planes of section to those shown in Figure 1. Boxed areas in B1-B3 are enlarged in F1-F3. ZLI, zona limitans intrathalamica; epi, epithalamus; th, thalamus; pth, prethalamus; emt, eminentia thalami; $h$, hypothalamus. Scale bars: $500 \mu \mathrm{m}$ (A1-E3), $50 \mu \mathrm{m}$ (F1-F3). 


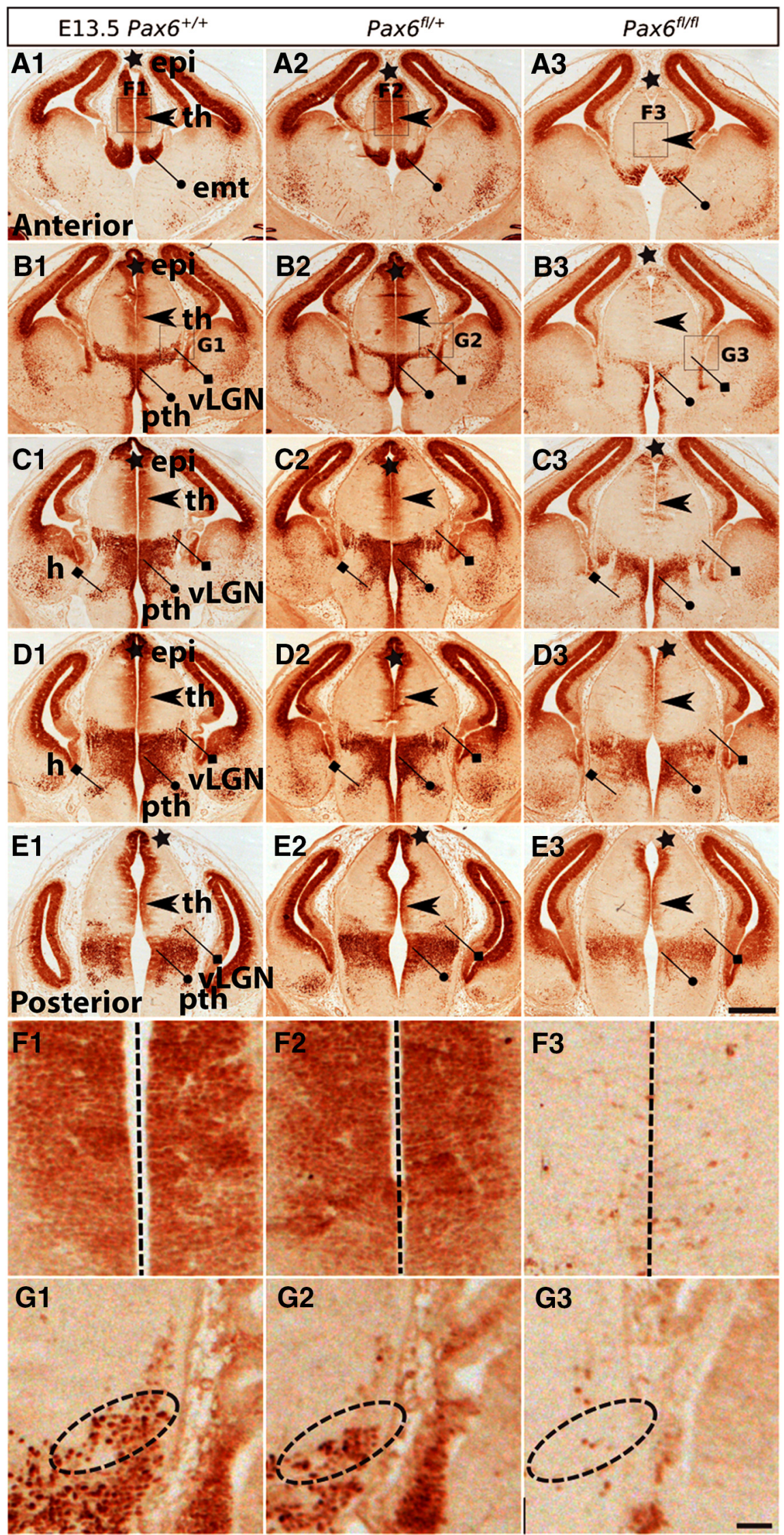

Figure 5. Pax6 expression in control and Pax6 mutant embryos at E13.5. Immunohistochemistry for Pax6 on a set of sections cut 
continued

through the diencephalon in similar planes of section to those shown in Figure 2. Boxed areas in A1-B3 are enlarged in F1-G3. vLGN, ventral lateral geniculate nucleus; epi, epithalamus; th, thalamus; pth, prethalamus; emt, eminentia thalami; h, hypothalamus. Scale bars: $500 \mu \mathrm{m}$ (A1-E3), $50 \mu \mathrm{m}(\boldsymbol{F} 1-F 3)$.

$P a x 6^{f l /+}$ embryos now appeared intermediate between controls and Zic4 ${ }^{\mathrm{Cre}}$;Pax $6^{\mathrm{fl} / f l}$ embryos. There were no detectable defects in the positions of the Pax6-expressing cells. The overall shapes and sizes of diencephalic structures appeared normal. These findings indicate that mutation of one copy of Pax6 in Zic4-lineage cells causes them to lower their Pax6 levels between E14.5 and E16.5, i.e., once they are postmitotic neurons, with levels in some falling below the threshold for detection.

\section{Cells of the vLGN, dLGN, and the VP nuclei are generated before E14.5}

We selected three thalamic nuclei to search for defects resulting from mutation of Pax6 in Zic4-lineage cells: vLGN, which contains a large proportion of Zic4-lineage cells at birth; dLGN, which contains an intermediate proportion of Zic4-lineage cells at birth; VP nuclei (VPM and VPL), which contain low numbers of Zic4-lineage cells at birth.

As a first step toward testing whether Pax6 mutation in Zic4-lineage cells affects the progenitors that give rise to these nuclei, we checked the ages at which vLGN, dLGN, and VP cells are generated. We injected BrdU into control embryos at E10.5-E13.5 and studied BrdU labeling at birth (P0). To help identify the nuclei we used several markers: COUP-TFI, COUP-TFII, LIM1/2, and Nkx2.2 (Fig. $9 A-D)$. COUP-TFI is expressed across most of the thalamic nuclei including the vLGN, dLGN, and VP. The expression level of COUP-TFI in the vLGN is lower than the surrounding nuclei such as the dLGN and VP and, within the vLGN, is highest in the middle of the nucleus (Fig. 9A). COUP-TFII is expressed strongly in the prethalamus and helped determine the anterior boundaries of the vLGN and VP (Fig. 9C). LIM1/2 and Nkx2.2 are strongly expressed in the vLGN but not in the dLGN or VP (Fig. 9B,D).

We counted BrdU-labeled cells as a proportion of all cells and as a proportion of Zic4-lineage (GFP+) cells in each nucleus (Fig. 9E,F). We found that the vast majority of cells in vLGN, dLGN, and VP are generated after E10.5 and before E13.5 (Fig. 9G,H).

\section{Effects of Pax6 mutation in Zic4-lineage cells on cell production}

We next used immunostaining for Ki67 (a marker of proliferating cells), Tuj1 (a marker of newly differentiating neurons) and phosphohistone $\mathrm{H} 3$ (pHH3; a marker of cells in M-phase of the cell cycle) together with short-term BrdU labeling to assess the activity of progenitors in regions that generate vLGN, dLGN, and VP at E11.5 and E12.5 (Fig. 10). We made measurements in three regions: $\mathrm{pTH}-\mathrm{C}$, which gives rise to thalamic nuclei including dLGN and VP; pTH-R, which contributes to nuclei including vLGN; and prethalamus (Fig. 10A). We sampled from four sections through each prethalamus and five through each
pTH-C and pTH-R, equally spaced from anterior to posterior, from four embryos of each age and genotype.

We first made measurements on all cells in the three regions, i.e., including both GFP+ and GFP- cells. When we examined the percentages of all cells that were proliferative based on their expression of Ki67, referred to as the growth fraction, we found small but significant decreases in Pax6 $6^{f l f l}$ pTH-C and pTH-R (Fig. 10B). When we measured this same parameter specifically in GFP+ (Zic4-lineage) cells, we found no significant effects of genotype (Fig. 10C). There were no intergenotypic differences in the numbers of $\mathrm{pHH}+$ cells in any region at either age (Fig. 10D,E). We then measured the proportions of proliferating cells $(\mathrm{Ki} 67+)$ that were in S-phase $(\mathrm{BrdU}+)$, which is an indication of their rate of proliferation (i.e., the longer the cell cycle, the lower the proportion of cells in S-Phase within the defined time window). When we examined all cells, we identified a small but significant decrease at E11.5 in Pax6 ${ }^{f / f l}$ pTH-R (Fig. 10F). When we examined GFP + cells alone, we found no significant effects of genotype (Fig. 10G).

These findings indicate that the loss of both copies of Pax6 in Zic4-lineage has a minor effect on proliferation, causing decreases in pTH-C and/or pTH-R at some ages, which was only detectable in the overall population of progenitors and not specifically the Zic4-lineage progenitors themselves.

\section{Pax6 mutation in Zic4-lineage cells increases their contribution to vLGN and dLGN}

We then analyzed the effects of Pax6 mutation in Zic4lineage cells on the numbers of these cells that contribute to vLGN, dLGN, and VP at PO (Fig. 11). We first estimated the total numbers of cells in each of these nuclei by sampling the densities of all counterstained cells in each nucleus and multiplying by its volume. Volumes were estimated using the ImageJ Volumest plugin on a series of 10 coronal sections with a regular interval of $60 \mu \mathrm{m}$ from each brain sample. We found no significant intergenotypic differences, indicating that Pax6 mutation in Zic4-lineage cells did not alter overall numbers of cells contributing to these nuclei (Fig. 11D-F).

We measured the proportions of cells in each of these nuclei that were Zic4-lineage (i.e., GFP+). We found that these proportions were significantly increased in the dLGN of Pax6 ${ }^{f l / f l}$ embryos (Fig. 11A,C,H). They were increased even more in the dLGN of Pax $6^{f l /+}$ embryos, with more than twice the normal proportions of Zic4-lineage cells contributing (Fig. $11 A, B, H)$. Proportions were also increased in the vLGN of Pax6 $6^{f l /+}$ embryos (Fig. $11 A, B, G$ ). The increases in the dLGN were seen in anterior sections in Pax $6^{f l / f l}$ embryos and throughout all sections in $P a x 6^{f l /+}$ embryos (Fig. 11H). The increases in the vLGN in Pax $6^{f l /+}$ embryos were greater in more posterior sections (Fig. 


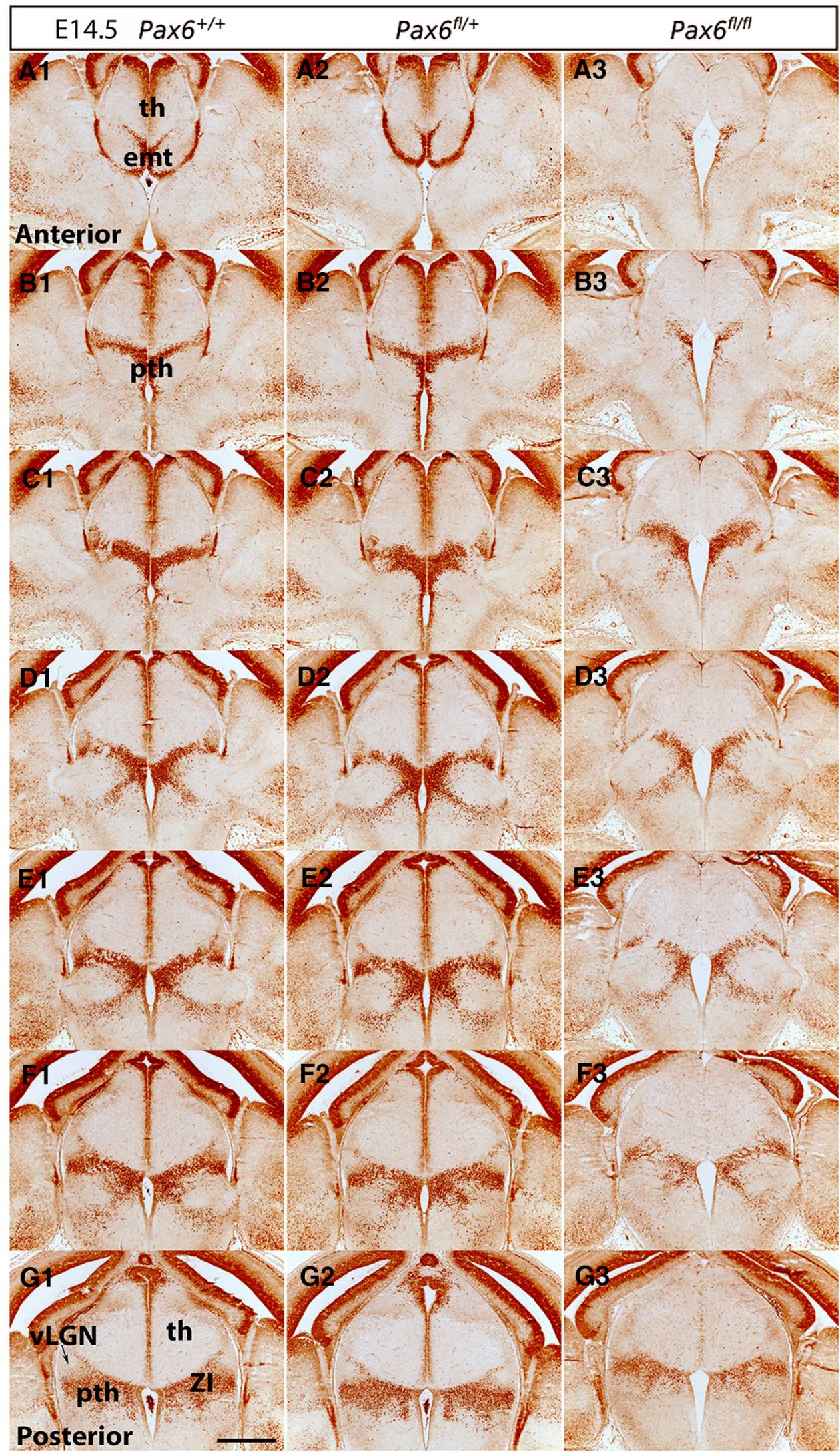

Figure 6. Pax6 expression in control and Pax6 mutant embryos at E14.5. (A1-G3) Immunohistochemistry for Pax6 on a set of sections cut through the diencephalon in similar planes of section to those shown in Figure 2, arranged from anterior (A1-A3) to posterior (G1-G3). Zl, zona incerta; vLGN, ventral lateral geniculate nucleus; th, thalamus; pth, prethalamus; emt, eminentia thalami. Scale bar: $500 \mu \mathrm{m}$. 


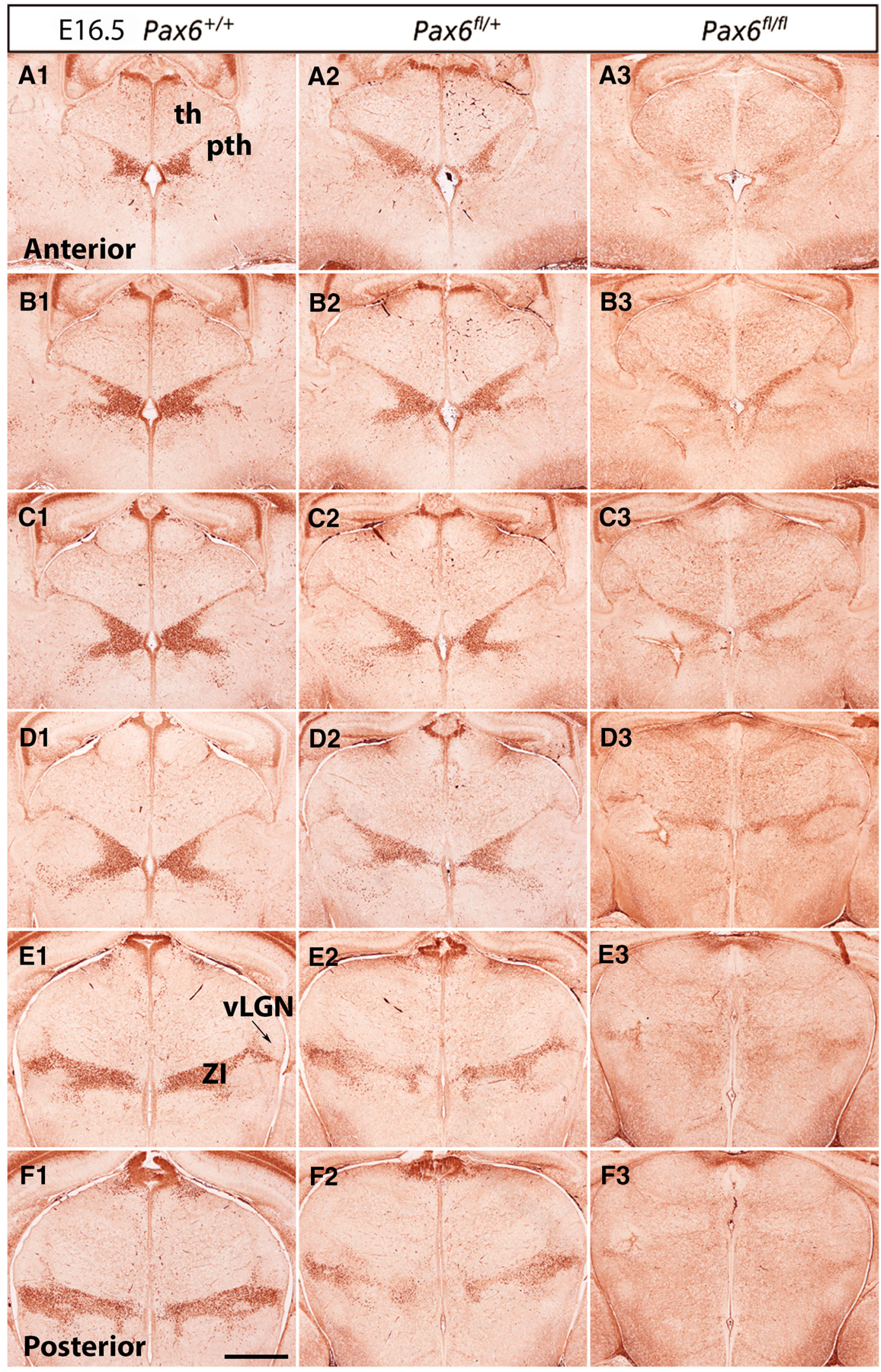

Figure 7. Pax6 expression in control and Pax6 mutant embryos at E16.5. (A1-F3)Immunohistochemistry for Pax6 on a set of sections cut through the diencephalon in similar planes of section to those shown in Figure 3, arranged from anterior (A1-A3) to posterior (F1-F3). Zl, zona incerta; vLGN, ventral lateral geniculate nucleus; th, thalamus; pth, prethalamus. Scale bar: $500 \mu \mathrm{m}$. 


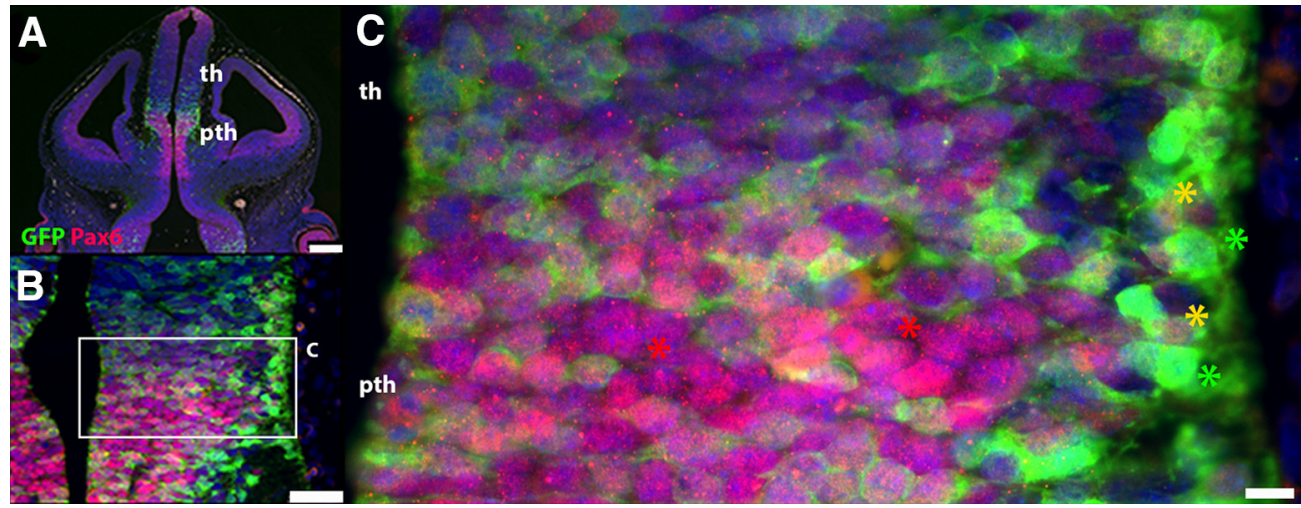

Figure 8. Diencephalic Zic4-lineage cells express Pax6. Double-immunohistochemistry for GFP (Zic4-lineage cells) and Pax6 at E11.5. Area outlined in $\boldsymbol{B}$ is enlarged in $\boldsymbol{C}$. Asterisks in $\boldsymbol{C}$ : yellow, examples of double-labeled cells; green, examples of cells labeled only with GFP; red, examples of cells labeled only for Pax6. Scale bars: $250 \mu \mathrm{m}(\boldsymbol{A}), 50 \mu \mathrm{m}(\boldsymbol{B}), 10 \mu \mathrm{m}(\boldsymbol{C})$.

11G). There were no intergenotypic differences in VP (Fig. 11/).

These findings indicate that the dLGN increases its content of Zic4-lineage cells at the expense of Zic4-nonlineage cells if the Zic4-lineage cells are Pax6 $6^{f / f l}$ or $\mathrm{Pax}^{\mathrm{fl}+}$. The vLGN increases its content of Zic4-lineage cells at the expense of Zic4-non-lineage cells if the Zic4lineage cells are $\mathrm{Pax}^{\mathrm{fl} /+}$.

\section{Discussion}

We have found that Zic4-lineage cells normally contribute $\sim 50 \%$ of vLGN cells, $\sim 25 \%$ of dLGN cells, and
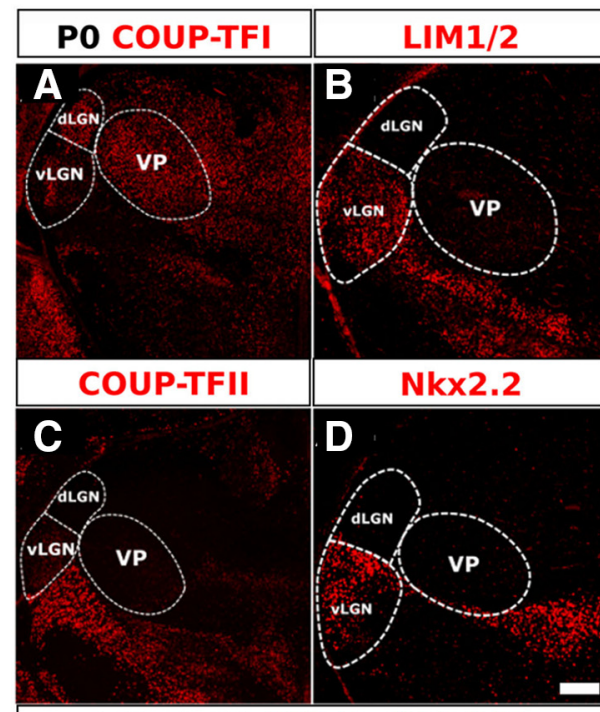

\section{PO vLGN GFP BrdU DAPI}

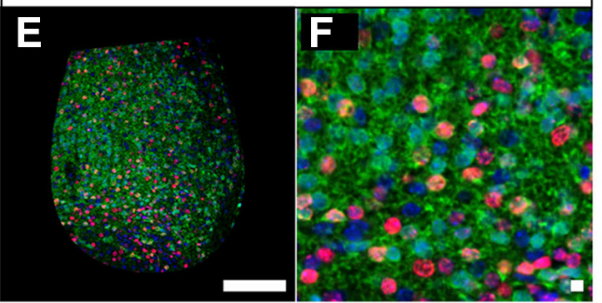

Proportion of vLGN cells born at different ages

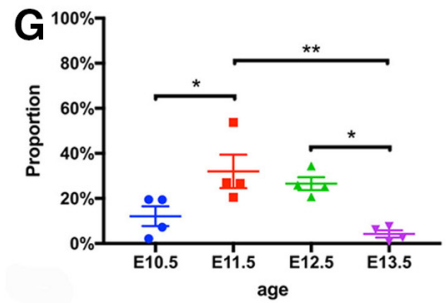

Proportion of dLGN cells born at different ages

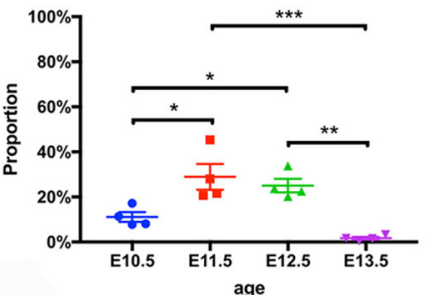

Proportion of VP cells born at different ages

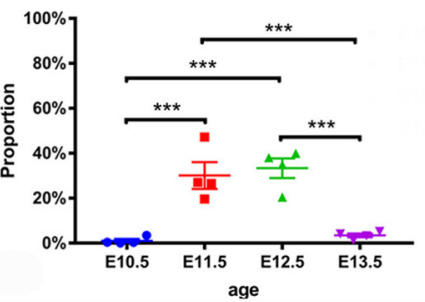

Proportion of GFP+ve vLGN cells born at different ages

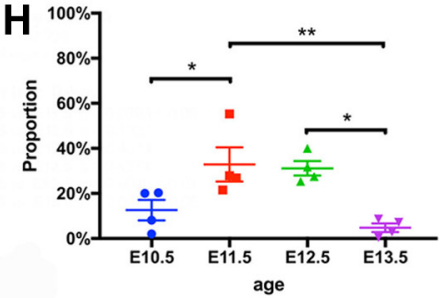

Proportion of GFP+ve dLGN cells born at different ages

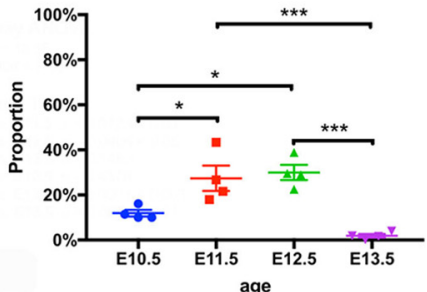

Proportion of GFP+ve VP cells born at different ages

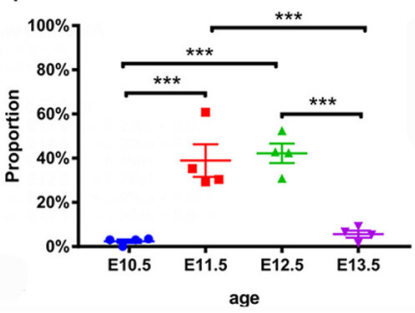

Figure 9. Birthdates of cells in the vLGN, dLGN, and VP. A-D, Immunohistochemistry at P0 with markers designed to help delineate borders of the thalamic nuclei analyzed here. Scale bar: $100 \mu \mathrm{m}$. $\boldsymbol{E}, \boldsymbol{F}$, Example of BrdU and GFP immunohistochemistry in vLGN. Scale bars: $100 \mu \mathrm{m}(\boldsymbol{E}), 10 \mu \mathrm{m}(\boldsymbol{F})$. G. Proportions of all cells in each nucleus that were BrdU+ after injection with BrdU at E10.5-E13.5. $\boldsymbol{H}$, Proportions of GFP-expressing cells in each nucleus that were BrdU+ after injection with BrdU at E10.5-E13.5. Data points are from individual animals. Mean \pm SEM are shown in each case. One-way ANOVA returned significant effects of age in all cases: (G) $\operatorname{vLGN~} F_{(3,12)}=7.729, p=0.0039 ;$ dLGN $F_{(3,12)}=13.56, p=0.0004 ; \operatorname{VP} F_{(3,12)}=20.76, p<0.0001 ;(\boldsymbol{H})$ vLGN $F_{(3,12)}=8.282, p=$ 0.0030; dLGN $F_{(3,12)}=15.41, p=0.0002 ;$ VP $F_{(3,12)}=23.26, p<0.0001$. Holm-Sidak's multiple comparisons tests were performed following one-way ANOVA: $* p<0.05 ; * * p<0.01 ; * * * p<0.001$. 


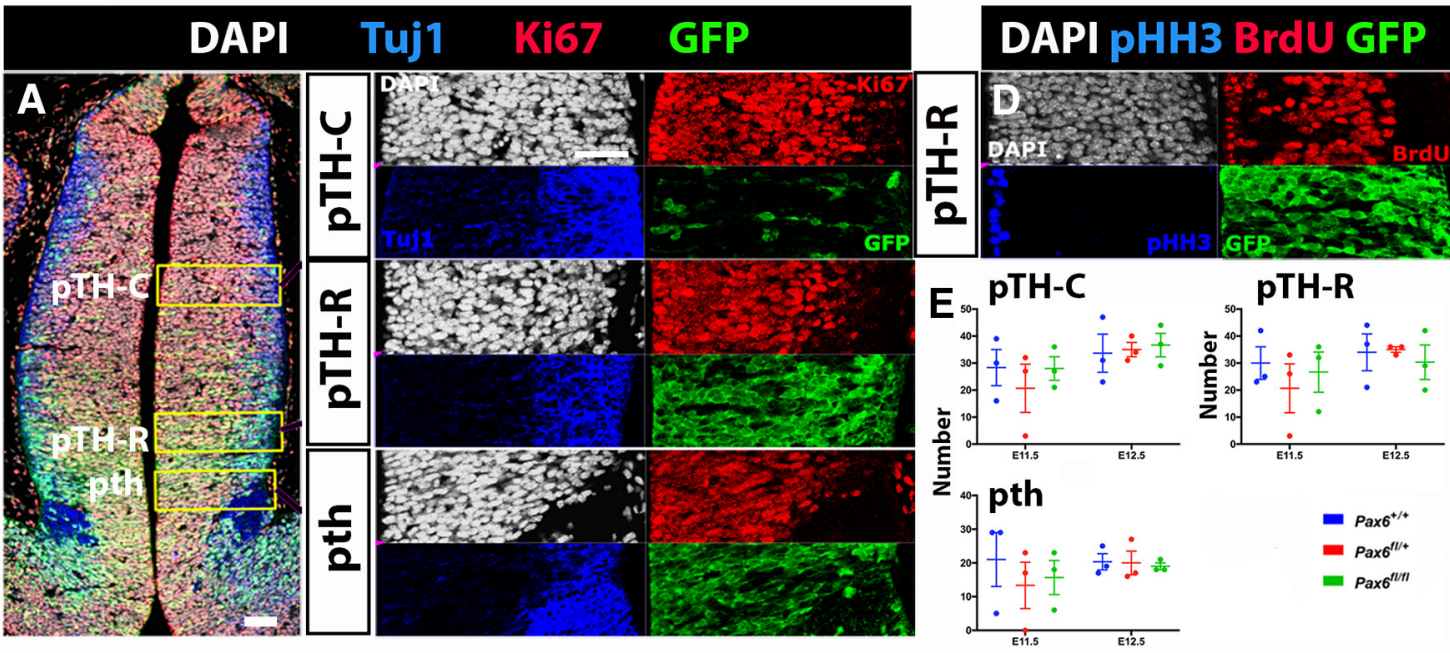

Growth Fraction $=$ nKi67 +/nDAPI $\times 100 \%$

B

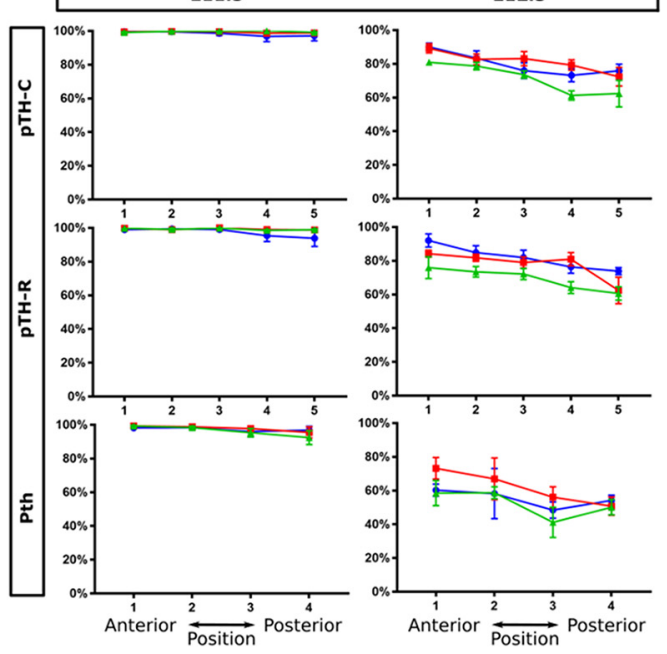

C
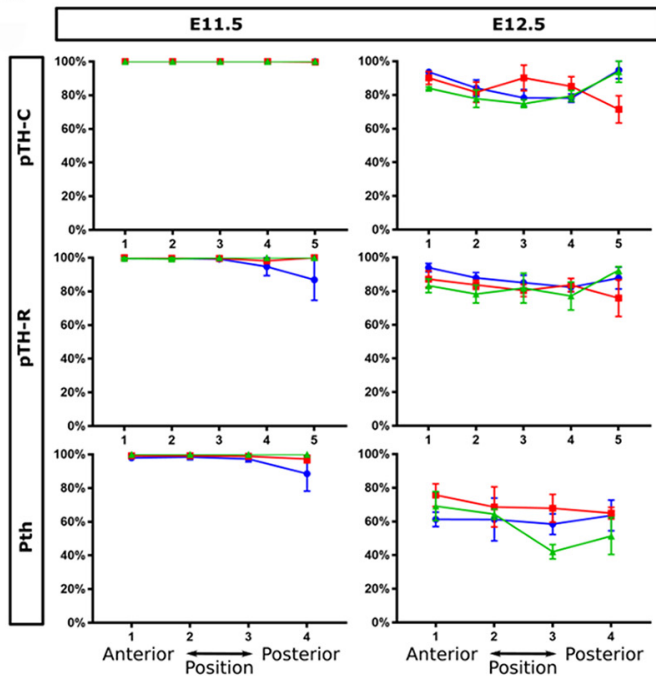
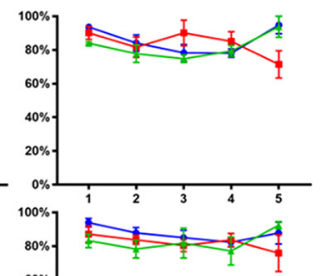

60
20
20

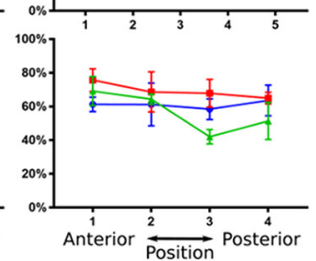

$F$

rate $=\mathrm{nBrdU}+/ \mathrm{nKi67}+\times 100 \%$

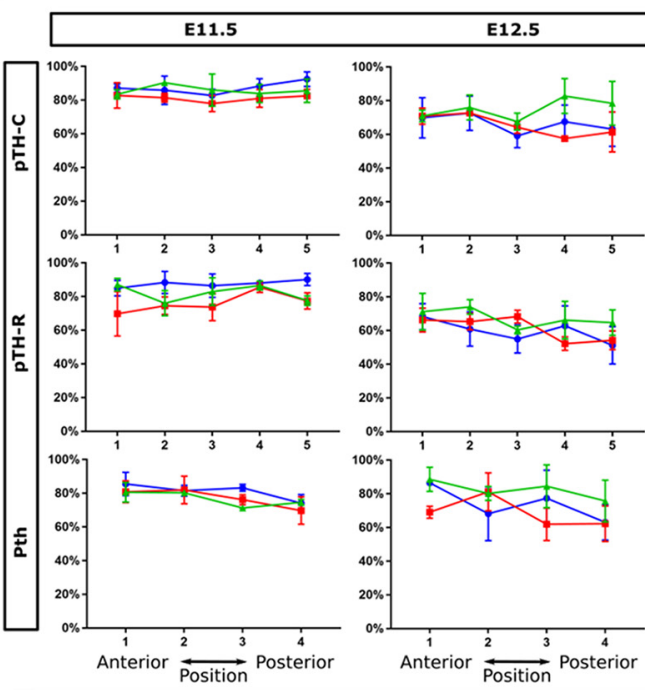

G

GFP+ Proliferation rate
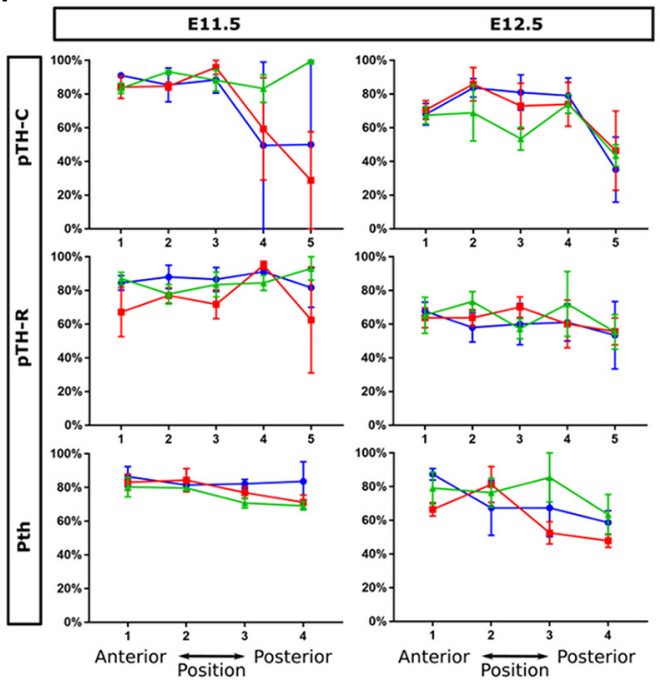

Figure 10. Effects of Pax6 mutation in Zic4-lineage cells on early diencephalic progenitor proliferation. $\boldsymbol{A}$, Triple immunostaining for Tuj1, Ki67, and GFP. Three regions of interest were selected for analysis, one midway through pTH-C, one in pTH-R and one in prethalamus (pth). Scale bars: $50 \mu \mathrm{m}$. B , Average growth fractions $( \pm S E M)$ in five equally spaced sections through pTH-C and pTH-R and four through prethalamus at E11.5 and E12.5; color coding for genotypes as in $\boldsymbol{E}$. Two-way ANOVA detected significant effects 


\section{continued}

of genotype only in pTH-C $\left(F_{(2,30)}=9.109, p=0.0008\right)$ and pTH-R $\left(F_{(2,30)}=11.97, p=0.0002\right)$ at E12.5 $(n=3$ embryos of each genotype), with $\mathrm{Pax} 6^{f / f l}$ embryos showing lower growth fractions at all levels (post hoc Tukey's multiple comparisons test, $p<0.01$ at all positions). $\boldsymbol{C}$, Average growth fraction for GFP+ cells only. There were no significant effects of genotype. $\boldsymbol{D}$, An example of triple immunostaining for $\mathrm{pHH} 3$, BrdU, and GFP in one region of interest. $\boldsymbol{E}$, Mean ( \pm SEM) counts of the total numbers of pHH3+ cells in all sampling regions from each domain for each genotype. There were no significant effects of genotype. $\boldsymbol{F}$, Average proliferation rates $( \pm$ SEM) in five equally spaced sections through pTH-C and pTH-R and four through prethalamus at E11.5 and E12.5; color coding for genotypes as in $\boldsymbol{E}$. Two-way ANOVA showed a significant effect of genotype in pTH-R at E11.5 $\left(F_{(2,30)}=4.206, p=0.0245\right)$, with lower values in Pax6 ${ }^{f / /+}$ embryos than in the other two genotypes. G, Average proliferation rates for GFP+ cells only. There were no significant effects of genotype.

$\sim 10 \%$ of VP cells at birth. Heterozygosity for a loss-offunction mutation of Pax6 in Zic4-lineage cells greatly increased the contribution that these cells make to the vLGN and dLGN, but not the VP. Homozygosity for the same mutation had a smaller effect on the contribution of Zic4-lineage cells to the dLGN and no effect on contribution to VLGN and VP.

These changes are most likely explained by a redistribution of mutant Zic4-lineage cells into the dLGN and vLGN. Our findings argue against an alternative explanation involving overproduction of mutant Zic4-lineage cells. When we tested whether Pax6 mutation, either heterozygous or homozygous, had an effect on the early proliferation of specifically the Zic4-lineage progenitors, we found none. We did find slight decreases in proliferation in some regions at some ages when we considered the overall populations of progenitors, both Zic4-lineage and Zic4-non-lineage. These finding suggest that some change in the Zic4-lineage cells, perhaps involving altered signaling, had a cell non-autonomous effect on the Zic4non-lineage cells. It does not, however, provide a straightforward explanation for the increased numbers of mutant Zic4-lineage cells in the dLGN and vLGN. Another reason that redistribution of postmitotic cells is a more likely mechanism than altered production is that the effects of heterozygosity for Pax6 mutation on Pax6 protein levels only became obvious in postmitotic cells and not in progenitors.

Figure 12 summarizes our model. The ZLI and the two progenitor domains posterior to it, pTH-R and pTH-C (Fig. $12 C, E$ ), express substantially different sets of regulatory genes. For example, the ZLI expresses Shh, pTH-R expresses transcription factors such as Nkx2.2 and Asc1, and $\mathrm{pTH}-\mathrm{C}$ expresses Neurog1 and Neurog2. Several previous fate mapping studies have used genetic tools to exploit these early gene expression patterns to link specific sets of progenitors with mature diencephalic nuclei (Vue et al., 2007, 2009; Delaunay et al., 2009; Jeong et al., 2011; Suzuki-Hirano et al., 2011). These studies showed that the ZLI and adjacent pTH-R contribute to the vLGN, whereas more caudal progenitors in $\mathrm{pTH}-\mathrm{C}$ contribute progressively to more caudal thalamic nuclei. In other words, the relative positions of thalamic progenitors are well preserved in the spatial arrangement of the nuclei they generate. Pax6 is expressed in a gradient by thalamic progenitors, with its lowest levels in pTH-R and no expression in the ZLI (Fig. 12C,E). This means that the Zic4-lineage cells that distribute to the vLGN and dLGN are derived mainly from progenitors that express little or no Pax6. If homozygous or heterozygous mutation causes Zic4-lineage cells to lose or lower their levels of Pax6, then these cells or their daughters preferentially distribute to nuclei that are generated from progenitors that express little or no Pax6. This suggests that the positional information encoded by the levels of Pax 6 in diencephalic progenitors is an important determinant of the eventual locations of their daughter cells.

A likely mechanism by which Pax6 levels effect the distribution of diencephalic neurons is through its regulation of cell adhesion molecules that cause cells to sort on the basis of their intercellular interactions. It has long been appreciated in many different systems that cells aggregate if they have similar levels of cadherins (Foty and Steinberg, 2005; Halbleib and Nelson, 2006). In the postnatal mouse brain, different thalamic nuclei express distinct combinations of cadherins: for example, the vLGN and dLGN express Cadherin 5, 8, and 11, whereas VP expresses mainly Cadherin 6 and 11 (Suzuki et al., 1997; Hirano and Takeichi, 2012). Both in vivo and in vitro studies have shown that Pax6 can regulate molecules such as R-cadherin, L1 cell adhesion molecule and N-CAM (Chalepakis et al., 1994; Edelman and Jones, 1995; Holst et al., 1997; Stoykova et al., 1997; Meech et al., 1999; Andrews and Mastick, 2003; Tyas et al., 2003).

Why Zic4-lineage cells heterozygous for a mutation of Pax6 cause a greater redistribution of Zic4-lineage cells affecting both dLGN and vLGN is not clear. One possibility stems from our observation that heterozygosity has a relatively late effect on Pax6 levels in postmitotic neurons, which contribute mainly to the prethalamus. A reduction of Pax6 levels in migrating prethalamic neurons might allow significant numbers of these cells to migrate in an abnormal direction across the boundary from prethalamus into the vLGN and dLGN. The numbers that do this might be greater than the numbers that sort incorrectly following loss of Pax6 from progenitors, as occurs in homozygous deletion. Progenitors might possess a degree of plasticity that allows them to compensate to some degree if they lose Pax6, thereby minimizing the consequences for later sorting of their postmitotic cells.

Whatever the cause of the strong effect of Pax6 heterozygosity, this finding is particularly relevant to human disease caused by PAX6 haploinsufficiency. In humans, heterozygous loss-of-function mutations affecting PAX6 cause a disorder with an incidence of $\sim 1 / 50,000$ live births. Patients show a range of neurologic and psychiatric symptoms including impaired auditory process- 

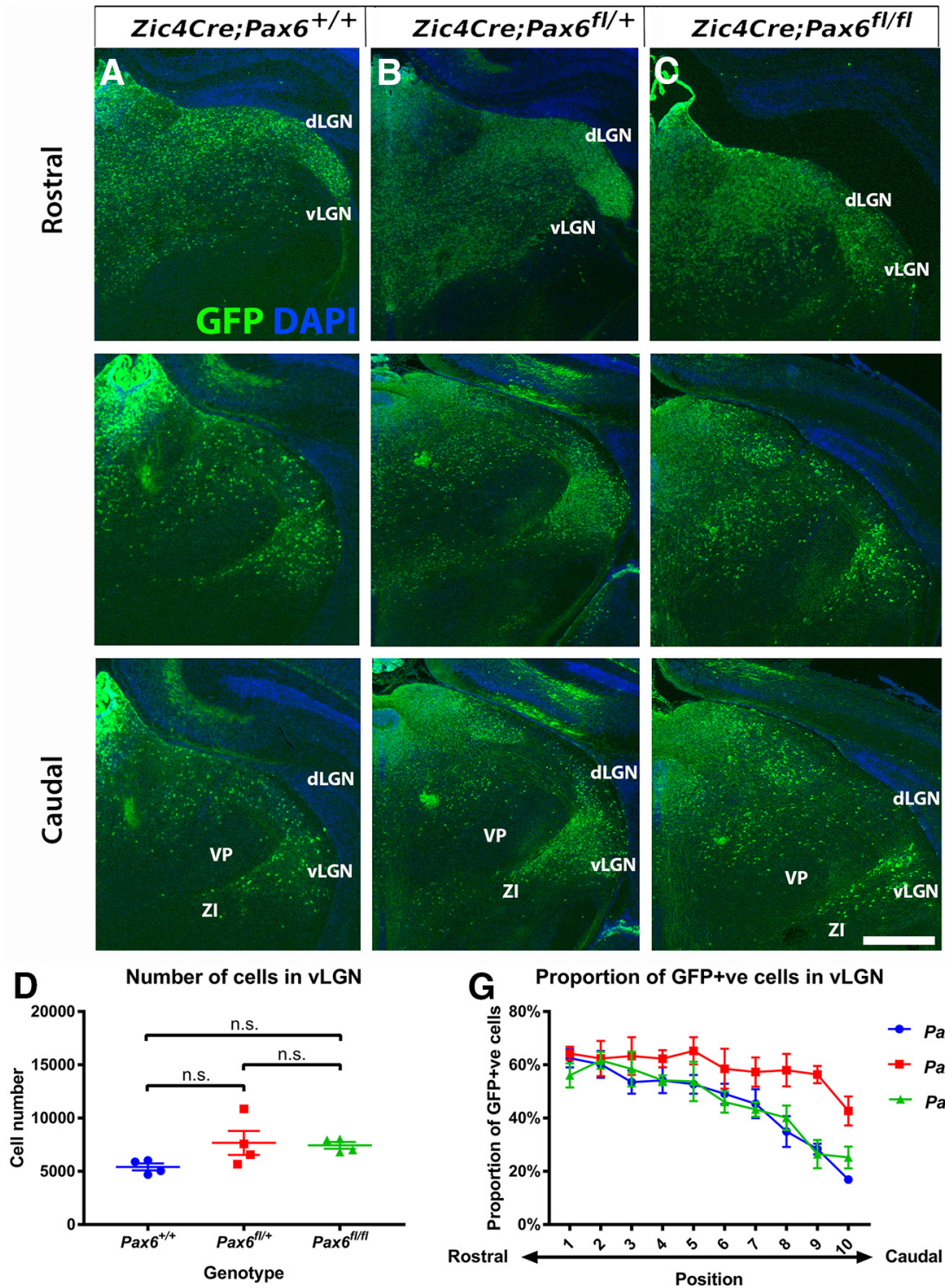

G Proportion of GFP+ve cells in vLGN
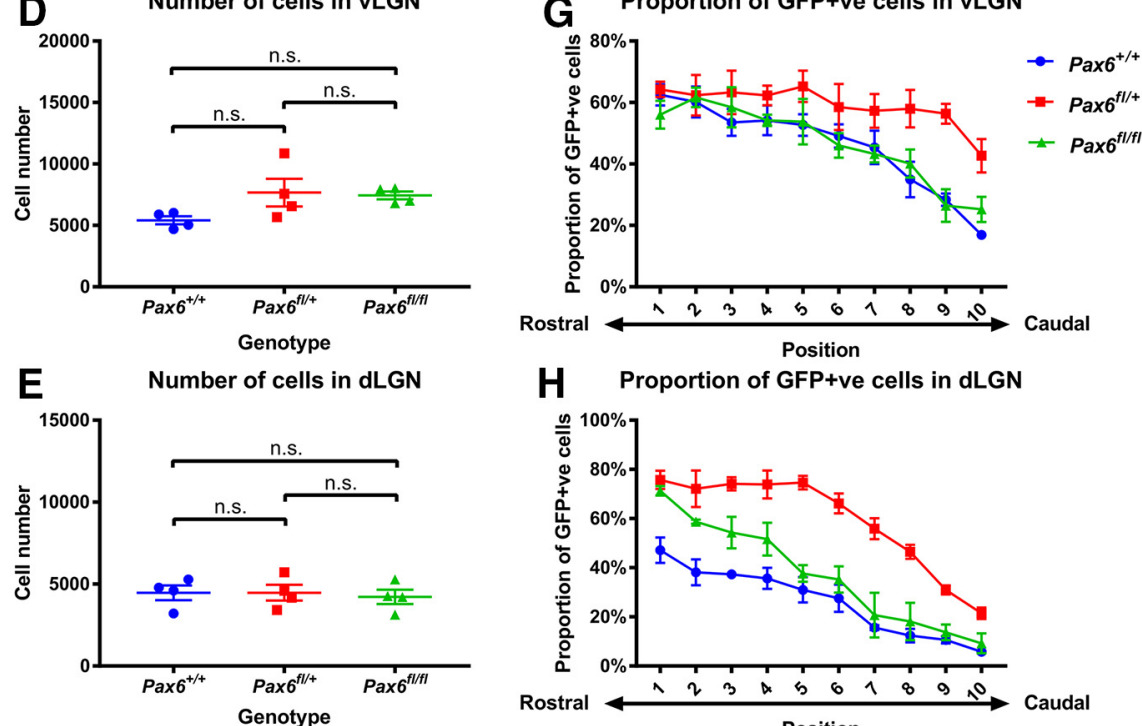

H Proportion of GFP+ve cells in dLGN
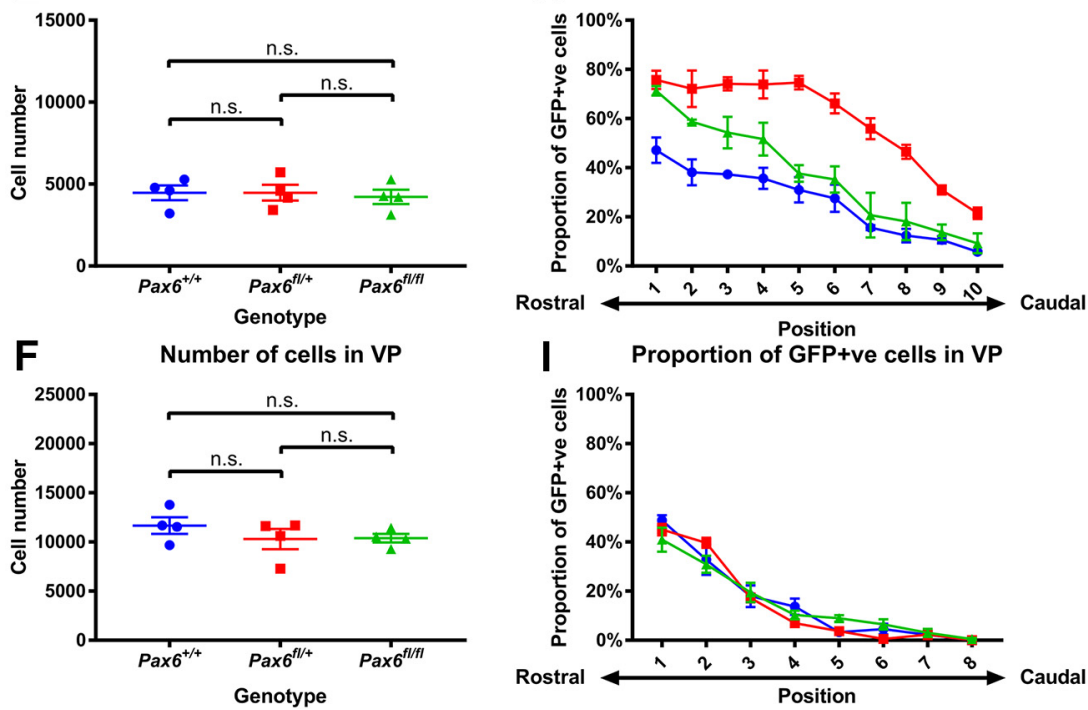

Figure 11. Pax6 mutation in Zic4-lineage cells increases their contribution to vLGN and dLGN. $\boldsymbol{A}-\boldsymbol{C}$, Sections from rostral to caudal 
continued

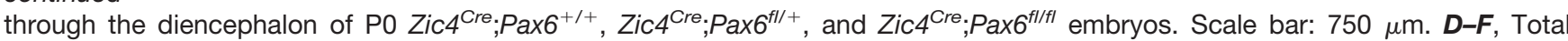
numbers of cells in VLGN, dLGN, and VP in four PO pups of each genotype; individual values, mean \pm SEM are shown. There were no significant effects of genotype. G-I, Proportions of GFP+ (i.e., Zic4-lineage) cells in sections equally spaced through the vLGN, dLGN, and VP of PO Zic4 ${ }^{C r e} ; P_{a x 6^{+/+}}$, Zic4 ${ }^{C r e} ; P_{a x 6^{f l /+}}$, and Zic4 ${ }^{C r e} ; P a x 6^{f l / f l}$ pups. In vLGN and dLGN, two-way ANOVA showed significant effects of genotype: vLGN, $F_{(2,90)}=23.98, p<0.0001$; dLGN, $F_{(2,60)}=140.4, p<0.0001$. In VP, there were no significant effects. Data are plotted using mean and SEM using at least three pups of each genotype ( $n=4$ for vLGN and $n=3$ for dLGN and VP).

ing, verbal function and social cognition, autism and mental retardation and altered functional connectivity in intrinsic neural networks (Sisodiya et al., 2001; Free et al., 2003; Mitchell et al., 2003; Ellison-Wright et al., 2004; Thompson et al., 2004; Bamiou et al., 2007; Umeda et al.,
2010; Pierce et al., 2014). These functional abnormalities are associated with structural defects of the cerebral cortex and its axonal tracts (Sisodiya et al., 2001). Mice with heterozygous loss-of-function mutations of Pax6 have rarely been used to explore possible pathologies
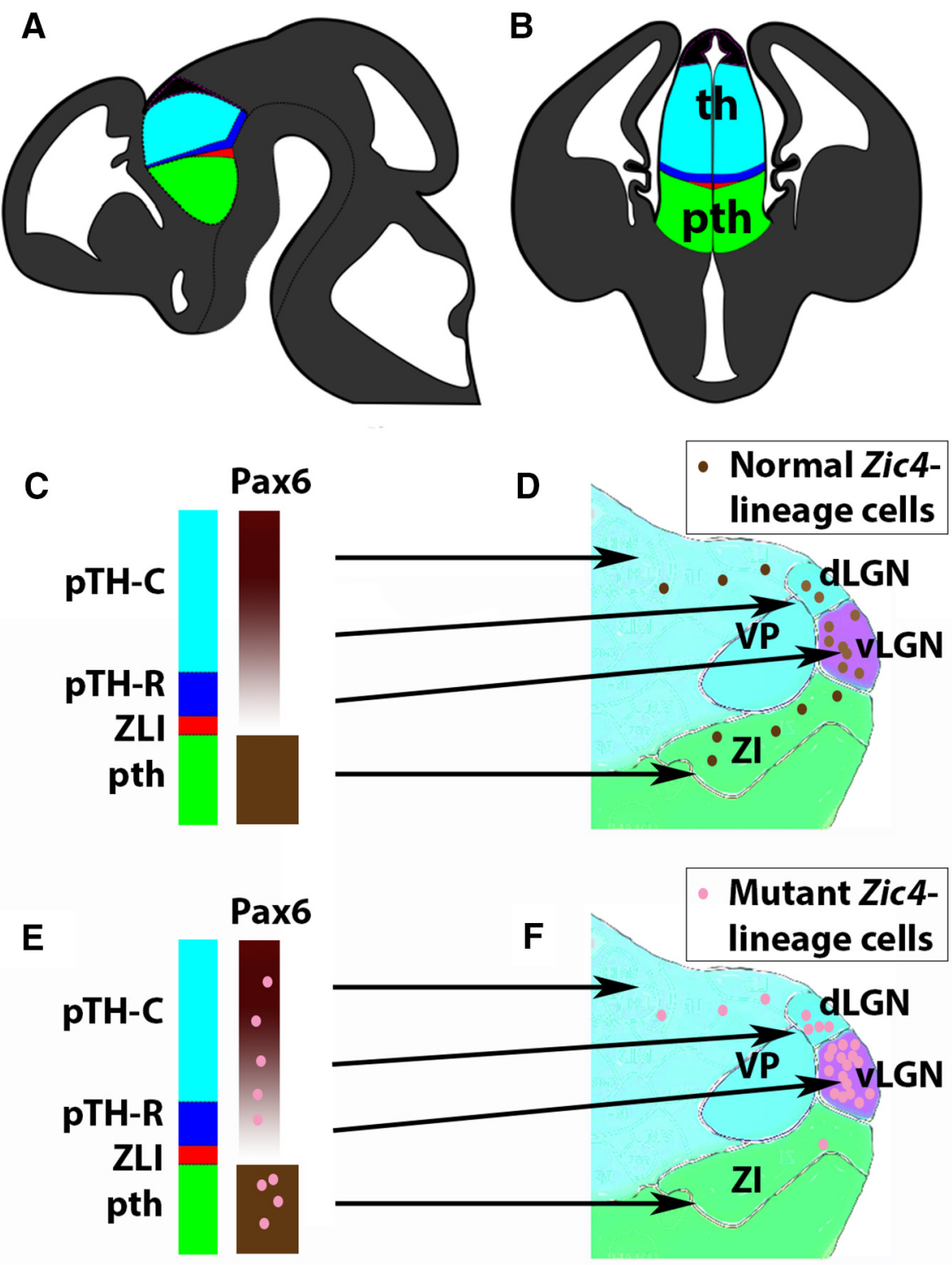

Figure 12. Model. A, B, Sections through the embryonic thalamus (th) and prethalamus (pth) showing the locations of the ZLI (red) and pTH-R (dark blue). C, D, Normally, Zic4-lineage cells from progenitors in the ZLI and pTH-R, which express little or no Pax6, contribute to the vLGN. Zic4-lineage cells from progenitors in rostral pTH-C (i.e., close to pTH-R), whose levels of Pax6 are relatively low, contribute to dLGN. Zic4-lineage cells in prethalamus (pth), which express Pax6 at high levels in both progenitors and postmitotic neurons, contribute to prethalamic regions including the ZI. $\boldsymbol{E}, \boldsymbol{F}$, Mutant Zic4-lineage cells concentrate in the vLGN and/or dLGN, which are derived from thalamic progenitors that normally express little or no Pax6. 
underlying the neurologic and psychiatric symptoms that patients experience. Although one study suggested a slight delay in the onset of corticogenesis in Pax6 \pm embryos (Schmahl et al., 1993), other work found no abnormalities of cortical development in these mice (Mi et al., 2013). Almost nothing is reported on the effects of Pax6 \pm heterozygosity on development of the diencephalon. Given that the dLGN is the relay nucleus for projections to the visual cortex, the findings of this study suggest that defects of the thalamus and geniculocortical pathway might be found in patients.

\section{References}

Andrews GL, Mastick GS (2003) R-cadherin is a Pax6-regulated, growth-promoting cue for pioneer axons. J Neurosci 23:98739880. Medline

Aruga J, Nagai T, Tokuyama T, Hayashizaki Y, Okazaki Y, Chapman VM, Mikoshiba K (1996a) The mouse zic gene family. Homologues of the Drosophila pair-rule gene odd-paired. J Biol Chem 271: 1043-1047. Medline

Aruga J, Yozu A, Hayashizaki Y, Okazaki Y, Chapman VM, Mikoshiba $\mathrm{K}$ (1996b) Identification and characterization of Zic4, a new member of the mouse Zic gene family. Gene 172:291-294. Medline

Bamiou DE, Free SL, Sisodiya SM, Chong WK, Musiek F, Williamson KA, van Heyningen V, Moore AT, Gadian D, Luxon LM (2007) Auditory interhemispheric transfer deficits, hearing difficulties, and brain magnetic resonance imaging abnormalities in children with congenital aniridia due to PAX6 mutations. Arch Pediatr Adolesc Med 161:463-469. CrossRef Medline

Caballero IM, Manuel MN, Molinek M, Quintana-Urzainqui I, Mi D, Shimogori T, Price DJ (2014) Cell-autonomous repression of Shh by transcription factor Pax6 regulates diencephalic patterning by controlling the central diencephalic organizer. Cell Rep 8:14051418. CrossRef Medline

Chalepakis G, Wijnholds J, Giese P, Schachner M, Gruss P (1994) Characterization of Pax-6 and Hoxa-1 binding to the promoter region of the neural cell adhesion molecule L1. DNA Cell Biol 13:891-900. CrossRef Medline

Delaunay D, Heydon K, Miguez A, Schwab M, Nave KA, Thomas JL, Spassky N, Martinez S, Zalc B (2009) Genetic tracing of subpopulation neurons in the prethalamus of mice (Mus musculus). J Comp Neurol 512:74-83. CrossRef Medline

Edelman GM, Jones FS (1995) Developmental control of N-CAM expression by Hox and Pax gene products. Philos Trans R Soc Lond B Biol Sci 349:305-312. CrossRef Medline

Ellison-Wright Z, Heyman I, Frampton I, Rubia K, Chitnis X, EllisonWright I, Williams SC, Suckling J, Simmons A, Bullmore E (2004) Heterozygous PAX6 mutation, adult brain structure and frontostriato-thalamic function in a human family. Eur J Neurosci 19: 1505-1512. CrossRef

Ericson J, Rashbass P, Schedl A, Brenner-Morton S, Kawakami A, van Heyningen V, Jessell TM, Briscoe J (1997) Pax6 controls progenitor cell identity and neuronal fate in response to graded Shh signaling. Cell 90:169-180. Medline

Foty RA, Steinberg MS (2005) The differential adhesion hypothesis: a direct evaluation. Dev Biol 278:255-263. CrossRef Medline

Free SL, Mitchell TN, Williamson KA, Churchill AJ, Shorvon SD, Moore AT, van Heyningen V, Sisodiya SM (2003) Quantitative MR image analysis in subjects with defects in the PAX6 gene. Neuroimage 20:2281-2290. Medline

Gaston-Massuet C, Henderson DJ, Greene ND, Copp AJ (2005) Zic4, a zinc-finger transcription factor, is expressed in the developing mouse nervous system. Dev Dyn 233:1110-1115. CrossRef Medline

Halbleib JM, Nelson WJ (2006) Cadherins in development: cell adhesion, sorting, and tissue morphogenesis. Genes Dev 20:31993214. CrossRef Medline
Hirano S, Takeichi M (2012) Cadherins in brain morphogenesis and wiring. Physiol Rev 92:597-634. CrossRef Medline

Holst BD, Wang Y, Jones FS, Edelman GM (1997) A binding site for Pax proteins regulates expression of the gene for the neural cell adhesion molecule in the embryonic spinal cord. Proc Natl Acad Sci USA 94:1465-1470. Medline

Horng S, Kreiman G, Ellsworth C, Page D, Blank M, Millen K, Sur M (2009) Differential gene expression in the developing lateral geniculate nucleus and medial geniculate nucleus reveals novel roles for Zic4 and Foxp2 in visual and auditory pathway development. $J$ Neurosci 29:13672-13683. CrossRef Medline

Jeong Y, Dolson DK, Waclaw RR, Matise MP, Sussel L, Campbell K, Kaestner KH, Epstein DJ (2011) Spatial and temporal requirements for sonic hedgehog in the regulation of thalamic interneuron identity. Development 138:531-541. CrossRef Medline

Jones E (2007) The thalamus. Cambridge, MA: Cambridge University Press.

Lamprecht MR, Sabatini DM, Carpenter AE (2007) CellProfiler: free, versatile software for automated biological image analysis. Biotechniques 42:71-75. CrossRef Medline

Lim Y, Golden J (2007) Patterning the developing diencephalon. Brain Res Rev 53:17-26. CrossRef Medline

Macdonald R, Barth KA, Xu Q, Holder N, Mikkola I, Wilson SW (1995) Midline signalling is required for $\mathrm{Pax}$ gene regulation and patterning of the eyes. Development 121:3267-3278. Medline

Martinez-Ferre A, Martinez S (2012) Molecular regionalization of the diencephalon. Front Neurosci 6:73. CrossRef Medline

Martynoga B, Morrison H, Price DJ, Mason JO (2005) Foxg1 is required for specification of ventral telencephalon and regionspecific regulation of dorsal telencephalic precursor proliferation and apoptosis. Dev Biol 283:113-127. CrossRef Medline

Meech R, Kallunki P, Edelman GM, Jones FS (1999) A binding site for homeodomain and Pax proteins is necessary for L1 cell adhesion molecule gene expression by Pax- 6 and bone morphogenetic proteins. Proc Natl Acad Sci USA 96:2420-2425. Medline

Merzin M (2008) Applying stereological method in radiology. Volume measurement. Bachelor's thesis. University of Tartu.

Mi D, Carr CB, Georgala PA, Huang YT, Manuel MN, Jeanes E, Niisato E, Sansom SN, Livesey FJ, Theil T, Hasenpusch-Theil K, Simpson TI, Mason JO, Price DJ (2013) Pax6 exerts regional control of cortical progenitor proliferation via direct repression of Cdk6 and hypophosphorylation of pRb. Neuron 78:269-284. CrossRef Medline

Mitchell TN, Free SL, Williamson KA, Stevens JM, Churchill AJ, Hanson IM, Shorvon SD, Moore AT, van Heyningen V, Sisodiya SM (2003) Polymicrogyria and absence of pineal gland due to PAX6 mutation. Ann Neurol 53:658-663. CrossRef Medline

Miyoshi G, Hjerling-Leffler J, Karayannis T, Sousa VH, Butt SJ, Battiste J, Johnson JE, Machold RP, Fishell G (2010) Genetic fate mapping reveals that the caudal ganglionic eminence produces a large and diverse population of superficial cortical interneurons. $J$ Neurosci 30:1582-1594. CrossRef Medline

Nakagawa $\mathrm{Y}$, Shimogori T (2012) Diversity of thalamic progenitor cells and postmitotic neurons. Eur J Neurosci 35:1554-1562. CrossRef Medline

Pierce JE, Krafft CE, Rodrigue AL, Bobilev AM, Lauderdale JD, McDowell JE (2014) Increased functional connectivity in intrinsic neural networks in individuals with aniridia. Front Hum Neurosci 8:1013. CrossRef Medline

Robertshaw E, Matsumoto K, Lumsden A, Kiecker C (2013) Irx3 and Pax6 establish differential competence for Shh-mediated induction of GABAergic and glutamatergic neurons of the thalamus. Proc Natl Acad Sci USA 110:E3919-E3926. CrossRef Medline

Rubin AN, Alfonsi F, Humphreys MP, Choi CK, Rocha SF, Kessaris N (2010) The germinal zones of the basal ganglia but not the septum generate GABAergic interneurons for the cortex. J Neurosci 30: 12050-12062. CrossRef

Schmahl W, Knoedlseder M, Favor J, Davidson D (1993) Defects of neuronal migration and the pathogenesis of cortical malformations 
are associated with Small eye (Sey) in the mouse, a point mutation at the Pax-6-locus. Acta Neuropathol 86:126-135. Medline

Sherman S, Guillery R (2002) The role of the thalamus in the flow of information to the cortex. Philos Trans R Soc Lond B Biol Sci 357:1695-1708. CrossRef Medline

Sherman S, Guillery R (2006) Exploring the thalamus and its role in cortical function. Cambridge, MA: MIT Press.

Sherman S, Guillery R (2011) Distinct functions for direct and transthalamic corticocortical connections. Journal of Neurophysiology 106:1068-1077. CrossRef Medline

Simpson TI, Pratt T, Mason JO, Price DJ (2009) Normal ventral telencephalic expression of Pax6 is required for normal development of thalamocortical axons in embryonic mice. Neural Dev 4:19. CrossRef

Sisodiya SM, Free SL, Williamson KA, Mitchell TN, Willis C, Stevens JM, Kendall BE, Shorvon SD, Hanson IM, Moore AT, van Heyningen V (2001) PAX6 haploinsufficiency causes cerebral malformation and olfactory dysfunction in humans. Nat Genet 28:214-216. CrossRef Medline

Stoykova A, Götz M, Gruss P, Price J (1997) Pax6-dependent regulation of adhesive patterning, R-cadherin expression and boundary formation in developing forebrain. Development 124:37653777. Medline

Suzuki SC, Inoue T, Kimura Y, Tanaka T, Takeichi M (1997) Neuronal circuits are subdivided by differential expression of type-II classic cadherins in postnatal mouse brains. Mol Cell Neurosci 9:433447. CrossRef Medline

Suzuki-Hirano A, Ogawa M, Kataoka A, Yoshida AC, Itoh D, Ueno M, Blackshaw S, Shimogori T (2011) Dynamic spatiotemporal gene expression in embryonic mouse thalamus. J Comp Neurol 519: 528-543. CrossRef

Thompson PJ, Mitchell TN, Free SL, Williamson KA, Hanson IM, van Heyningen V, Moore AT, Sisodiya SM (2004) Cognitive functioning in humans with mutations of the PAX6 gene. Neurology 62:12161218. Medline

Tyas DA, Pearson H, Rashbass P, Price DJ (2003) Pax6 regulates cell adhesion during cortical development. Cereb Cortex 13:612-619. Medline

Umeda T, Takashima N, Nakagawa R, Maekawa M, Ikegami S, Yoshikawa T, Kobayashi K, Okanoya K, Inokuchi K, Osumi N (2010) Evaluation of Pax6 mutant rat as a model for autism. PLoS One 5:e15500. CrossRef Medline

Vue TY, Aaker J, Taniguchi A, Kazemzadeh C, Skidmore JM, Martin DM, Martin JF, Treier M, Nakagawa Y (2007) Characterization of progenitor domains in the developing mouse thalamus. J Comp Neurol 505:73-91. CrossRef Medline

Vue TY, Bluske K, Alishahi A, Yang LL, Koyano-Nakagawa N, Novitch B, Nakagawa $Y$ (2009) Sonic hedgehog signaling controls thalamic progenitor identity and nuclei specification in mice. $J$ Neurosci 29:4484-4497. CrossRef Medline 